Martina Ožanić - Ksenija Škarić

Konzervatorski odjel u Zagrebu - Hrvatski restauratorski zavod

\title{
Iz kulta u muzej i natrag: putovanje jedne turopoljske umjetnine
}

\author{
Izvorni znanstveni rad - Original scientific paper \\ Primljen - Received 21. 6. 2017. \\ UDK 726:27-526.2(497.5)"16"
}

\section{Sažetak}

Članak obrađuje proces demuzealizacije i resakralizacije pobočnog oltara Preobraženja Gospodinova koji je stotinjak godina čuvan $u$ Muzeju grada Zagreba, od čega je posljednja desetljeća proveo u depou. Porijeklom iz kapele svetih Fabijana i Sebastijana u Kučama, danas župa Vukovina, a nekad Staro Ciče, oltar je bio uklonjen pred rušenje stare drvene kapele 1909. godine i gradnju nove zidane koja je potom uslijedila na istom mjestu. Prije povrata u kapelu oltar je restauriran, a usporedna povijesnoumjetnička i restauratorska istraživanja otkrila su niz dosad nepoznatih činjenica, uključivo dataciju, prethodne posvete oltara, naručitelja/donatora i slijed njegovih selidbi.

Ključne riječi: Kuče, Staro Čiče, demuzealizacija, resakralizacija, drveni oltar, 17. stoljeće, Johannes Komersteiner, Muzej grada Zagreba

S obzirom na to da su oltari iz prve polovice 17. stoljeća u kontinentalnoj Hrvatskoj toliko 'prorijeđeni' da je sačuvano tek nekoliko više ili manje preinačenih cjelina ili fragmenata, dragocjene su nam sve nove spoznaje o njima, osobito kada se radi o umjetninama visoke umjetničke razine. ${ }^{1}$ Kada se tome pridruži podatak da se jedan takav oltar nakon gotovo stoljeća pohrane u muzeju vraća u crkvu negdašnjem vlasniku, razloga je više nego dovoljno da se nađe u žarištu našeg zanimanja te da, po prvi put, bude predmet cjelovitijega povijesnoumjetničkog istraživanja. Nove spoznaje proistekle su iz usporednog materijalnog i arhivskog istraživanja oltara Preobraženja Gospodinova iz Muzeja grada Zagreba koji je prije povrata negdašnjem vlasniku - danas župi Vukovina - restauriran u Hrvatskom restauratorskom zavodu (sl. 1). ${ }^{2}$

\section{Oltar Preobraženja Gospodinova u Muzeju grada Zagreba}

Oskudnom broju u većoj ili manjoj mjeri očuvanih drvenih retabala iz prve polovine 17. stoljeća u sjevernoj Hrvatskoj pripada i oltar koji se više od stotinu godina nalazio u fundusa Muzeja grada Zagreba. Riječ je o nekadašnjemu bočnom oltaru iz kapele sv. Fabijana i Sebastijana u naselju
Kuče, danas filijalnoj crkvi Župe Pohoda Marijina u Vukovini. Povijest tog oltara, sada posvećenog Preobraženju Gospodinovu, obilježena je višestrukim promjenama titulara i lokaliteta. U Muzej grada Zagreba dopremljen je spletom okolnosti. Naime, kako župnik Adam Podolšak detaljno izvješćuje u Župnoj spomenici, dotrajala drvena kapela iz 17. stoljeća u Kučama (sl. 2) porušena je 1909. godine, a nova sazidana prema nacrtu arhitekta Hectora Friedricha Wilhelma Maria von Eckhela (Trst, 1855. - Zagreb, 1934.) $)^{3}$ te posvećena 1911. godine. ${ }^{4}$ Netom prije, 1907 . godine, osniva se u Zagrebu Gradski muzej (Muzej slobodnog i kraljevskog glavnog grada Zagreba) potporom Družbe Braće Hrvatskoga Zmaja, ponajviše zahvaljujući zalaganjima prvoga velikog meštra Družbe - Emilija Laszowskog (Brlog kraj Ozlja, 1868. - Zagreb, 1949.), svestranog povjesničara, arhivista i njegova prvog ravnatelja i kustosa. ${ }^{5}$ Gotovo istovremeno Laszowski zajedno s povjesničarem Jankom Barlèom (Budanje kod Vipave, 1869. - Zagreb, 1941.) obilazi spomenike turopoljskoga kraja. Barlè je prvi, 1909. godine, objavio kratak povijesni pregled kapele u Kučama s opaskom da su joj »izbrojani dani, jer se ima do skora porušiti i mjesto nje sagraditi nova. ${ }^{6}$ Njihovo istraživanje rezultiralo je nezaobilaznom monografijom u četiri sveska »Povijest plem. Općine Turopolja nekoć Zagrebačko polje zvane«, čiji je drugi svezak 


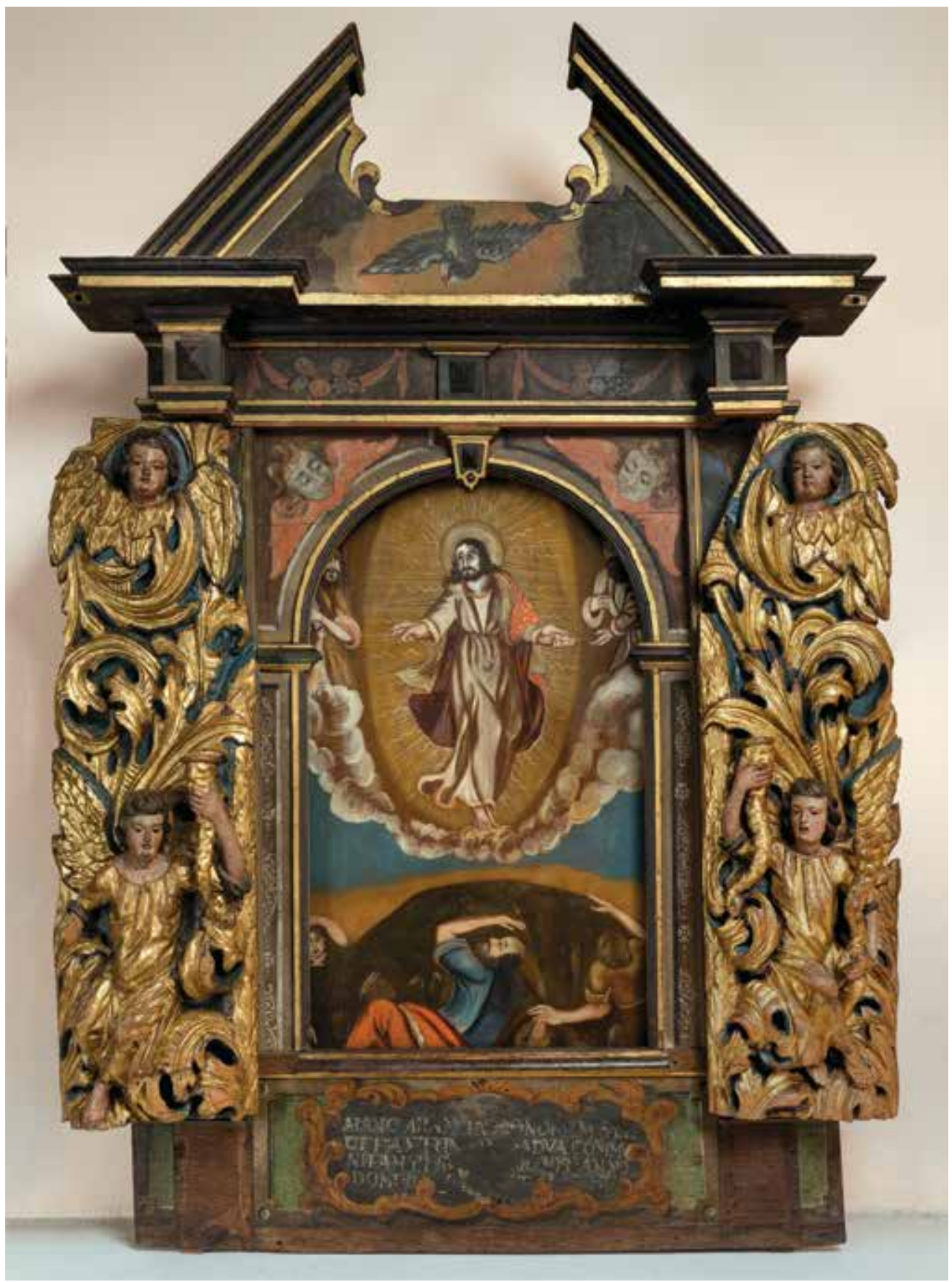

1. Kuče, kapela sv. Fabijana i Sebastijana, oltar Preobraženja Gospodinova nakon restauriranja (foto: N. Oštarijaš, 2017., Fototeka HRZ-a)

Kuče, chapel of St Fabian and St Sebastian, altar of the Transfiguration after the restoration works

„Općinske uredbe, povijest crkvi i odnosi nekih crkvenih redova prema općini turopoljskoj« izdan 1911. godine. U njemu su prikupljeni ažurirani podaci poput onoga da se nova zidana kapela u Kučama »doista već i gradi «, ${ }^{7}$ premda je publicirana fotografija glavnog oltara i djelomice svetišta ona ista kao i prije objavljena u Barlèovu članku iz 1909. godine dok je još drvena kapela stajala, dakle, prije 8. kolovoza 1909. godine. Barlè i Laszowski u kapeli zatiču inventar od kojega je u novoizgrađenoj kapeli zadržan samo spomenuti, obnovljen i preinačen glavni oltar, ${ }^{8}$ dok o sudbini preostalih umjetnina koje su bile uklonjene ne donose vijesti. ${ }^{9}$ Dio tog inventara nestao je bez traga, no jedan dio dopremljen je u Gradski muzej, bez sumnje zahvaljujući netom uspostavljenom kontaktu župnika Podolšaka s Laszowskim koji ga je, vrlo vjerojatno, potaknuo da inventar iz porušene drvene kapele pokloni novoutemeljenom Muzeju. Naime, otvorenim pozivima u dnevnom tisku poticalo se »rodoljubivo gradjanstvo zagrebačko, kao i sve hrvatske rodoljube« da pomognu oblikovati fundus predmetima koji su »važni po kulturu i historiju grada Zagreba i neposredne okoline«, a da je odaziv bio uspješan svjedoče objave brojnih darovatelja. ${ }^{10}$ U predmetnim muzejskim karticama u Katalogu predmeta 

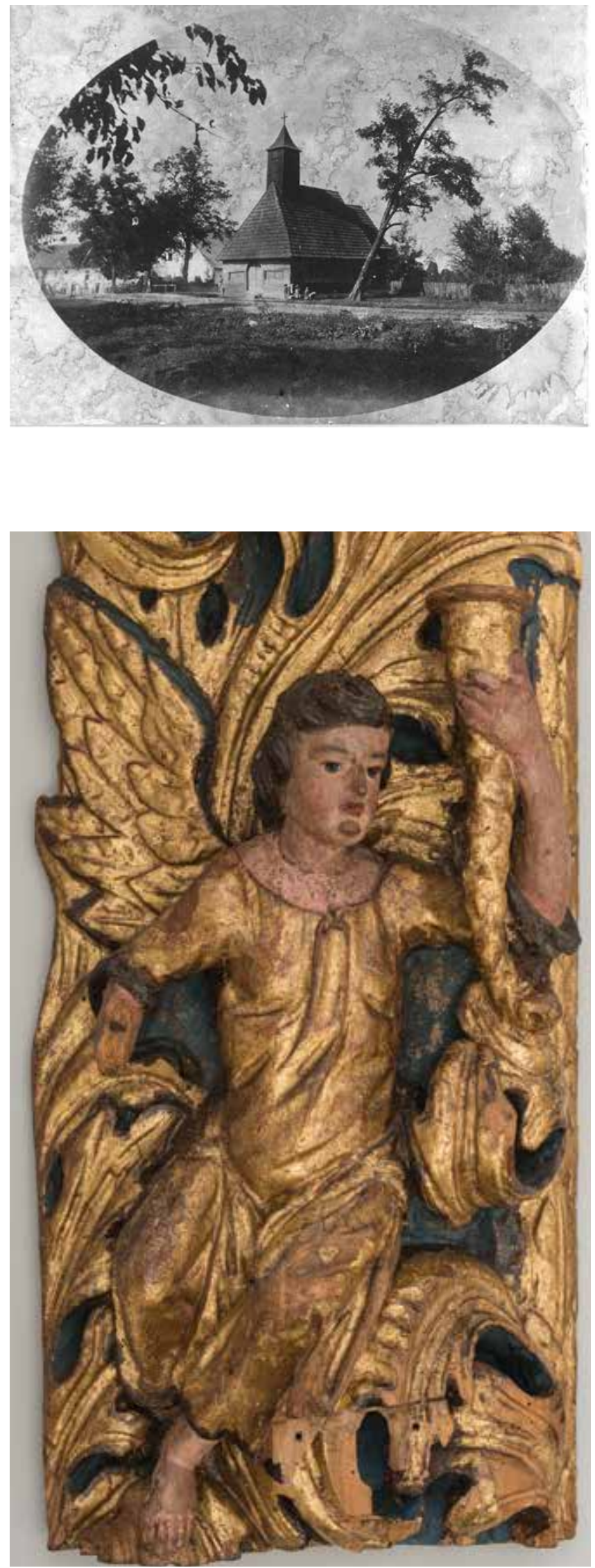

3. Oltar Preobraženja Gospodinova, detalj lijevoga velikog reljefa (foto: G. Tomljenović, 2017., Fototeka HRZ-a)

Altar of the Transfiguration, detail of the large relief to the left
2. Negdašnja drvena kapela sv. Fabijana i Sebastijana u Kučama (Muzej Turopolja, presnimak Joze Vranića iz 1978. u Fototečnoj službi Ministarstva kulture, neznani autor)

Former wooden chapel of St Fabian and St Sebastian in Kuče

muzeja, koje je Laszowski osobno inventirao, zabilježio je da su predmeti iz Kuča dar župnika Muzeju 1911. godine. ${ }^{11}$ Među evidentiranim umjetninama nalaze se i slika Preobraženja Gospodinova (ulje na platnu, bez okvira, $105 \times 84 \mathrm{~cm}$, MGZ361, stari Inv. br. BHZ666) te okvir oltara bez slike s akantovim krilima (okvir oltara, drvorezbareno, polikromirano, $200 \times 120 \mathrm{~cm}$, MGZ-362, akantova krila, drvorezbareno, polikromirano, pozlaćeno, MGZ 5681, MGZ 5682 a, b; stari Inv. br. BHZ670), koji su tema ovoga istraživanja.

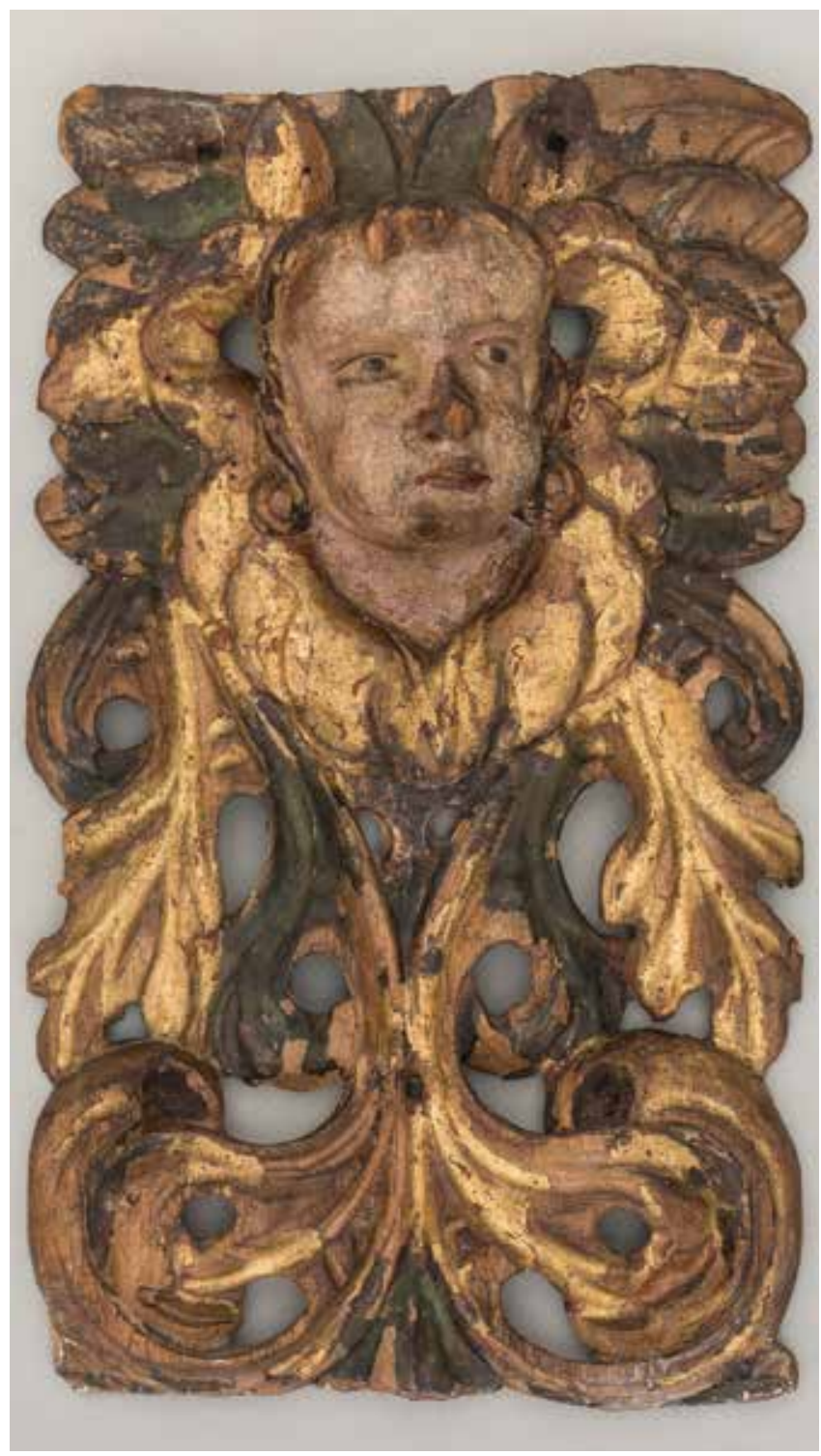

4. Oltar Preobraženja Gospodinova, mali reljef (foto: G. Tomljenović, 2017., Fototeka HRZ-a)

Altar of the Transfiguration, small relief 
Dospjevši u Muzej, necjeloviti inventar kapele iz Kuča složen je i izložen kao assemblage skrojen od dijelova oltara i zasebno dopremljene slike. Izgleda da oltar ni dok je bio u kapeli nije imao sačuvane originalne stupove ni oltarna krila, te da je već tada bio sastavljen od starijeg retabla i dvaju nešto mlađih reljefa s anđelima lučonošama koji proviruju iz bujnoga, duboko rezanog akantova lišća (sl. 3), kako bi se prikrila njegova fragmentarnost. To se može zaključiti prema najranijoj predmetnoj kartici u Muzeju prema kojoj je zaprimljen »Okvir oltara. Bez slike, sa strane ornamenti rezani sa angjelima, koji drže svjećnjake. Gore atika.«"12 Spomenute reljefe s likovima anđela lučonoša među akantovim ornamentom pripisala je Nela Tarbuk radionici kipara Johannesa Komersteinera (Kitzbühel/Sankt Johann in Tirol, prva polovina XVII. stoljeća - Zagreb, oko 1695.), zaključivši da se vjerojatno radi o negdašnjim oltarnim krilima glavnoga oltara kapele te utvrdivši srodnosti s drugim Komersteinerovim anđelima, posebice onima koji su stajali na glavnom oltaru u kapeli sv. Andrije u Lazu. ${ }^{13} \mathrm{~S}$ obzirom na sličnosti u rezu akanta na glavnom oltaru u Jakuševcu iz 1691. godine, kao i spomenute sličnosti s oltarom u Lazu, čije je pretpostavljeno vrijeme nastanka između 1691. i 1695. godine, Nela Tarbuk zaključuje da su i reljefi u Kučama nastali u zadnjem desetljeću 17. stoljeća. ${ }^{14}$ U odnosu na rad majstora Johannesa, šake i stopala dosta su grubo rezbareni, stoga je moguće da je izrada povjerena i nekom od pomoćnika u radionici. Međutim, za Komersteinera tipičan postupak dubljenja zjenica i šarenica u negativu koji nalazimo na dječjim figurama i kipovima anđela, primjerice na skulpturama na bočnim oltarima sv. Roka i sv. Marije Magdalene u kapeli sv. Petra u Gotalovcu (izvorno iz zagrebačke stolnice), i ovdje je prisutan. Taj postupak kiparu omogućuje da i bez polikromije postigne učinak pogleda, zahvaljujući sjeni koju konkavno udubljenje stvara. Spomenimo i još jedan osobito zanimljiv detalj. Način na koji su ti akantovi reljefi uz unutarnji rub zakrivljeno rezani upućuje da su vrlo vjerojatno nekada bili dio lučno uokvirenog otvora, a nije isključena ni mogućnost da je akantov ornament gradio oltarnu konstrukciju. $\mathrm{U}$ tom bi se slučaju radilo o retablu građenom ornamentom akantova lista (njem. Akanthusaltar) kakvih u nas nema sačuvanih prije 1719. godine. ${ }^{15}$

Cjelina oltara upotpunjena je još jednim manjim reljefom $s$ krilatom anđeoskom glavicom koja izranja iz akantove grane (sl. 4), a za koji nije zabilježeno dolazi li iz Kuča. Taj je reljef bio smješten na čeonu stranu postamenata za nosače na predeli. Naglašena simetričnost akantova motiva i njegova pojednostavljena forma plitke reljefnosti, uz drugačije modeliranu kosu i lice anđela, upućuju na drugo, za sada, neznano autorstvo te je moguće da potječe s nekoga drugog oltara.

Uvid u muzejske kartice otkriva da je oltar stigao u Muzej s već pripojena dva velika reljefa na mjestima nosača, no bez pripadajuće oltarne pale, premda su u vrijeme pred rušenje drvene kapele Laszowski i Barlè zatekli oltar sv. Antuna Padovanskog s pripadajućom slikom. ${ }^{16}$ Ipak, ona se nije sačuvala, nego samo istoimena slika koja je također visjela na zidu. ${ }^{17} \mathrm{U}$ novome muzejskom okruženju oltar je stoga združen sa slikom Preobraženja Gospodinova iz 1762. godine, koja je nekoć pripadala bočnom oltaru istoga titulara, a od

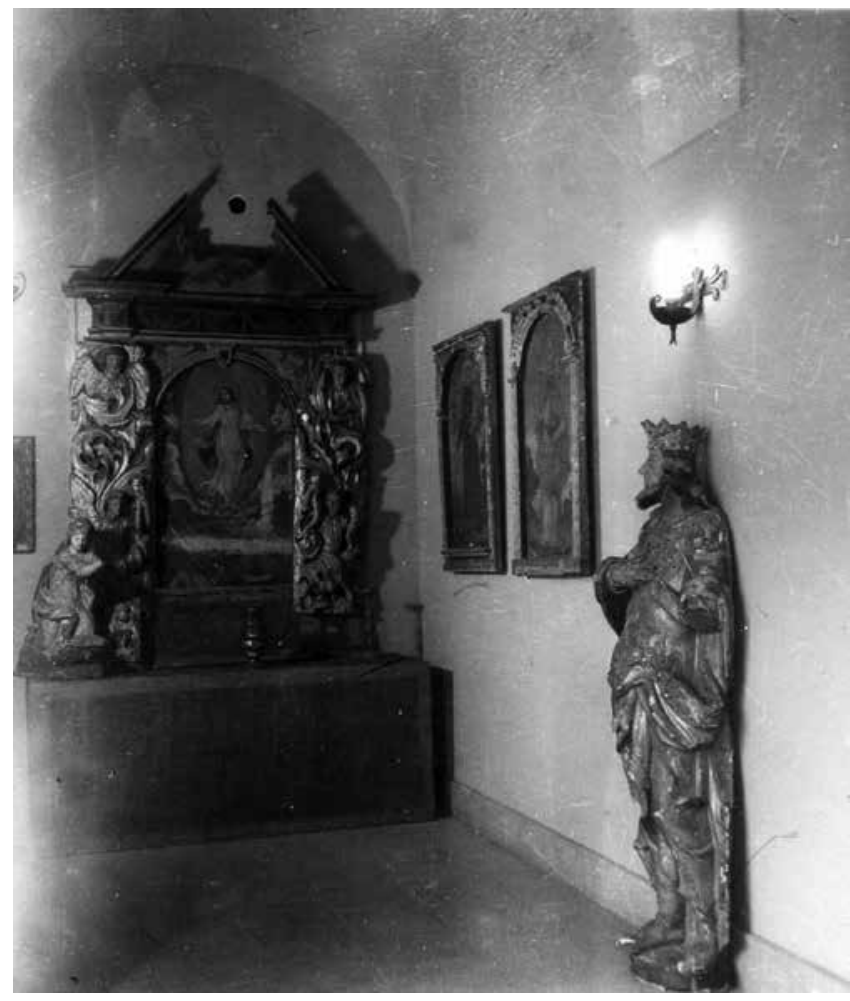

5. Muzej grada Zagreba, stalni postav u Opatičkoj 8, Detalj crkvene zbirke, 1945. godine (MGZ, inv. ozn. F-73)

Municipal Museum of Zagreb, permanent exhibition at Opatička No. 8, detail of the collection of religious art, 1945

1799. godine visjela samostalno na zidu jer je oltar posvećen novom zaštitniku, svetom Andriji.

O smještaju oltara u muzejskim prostorima arhivska građa nudi tek škrte podatke u kojima često nedostaje dodatni opis

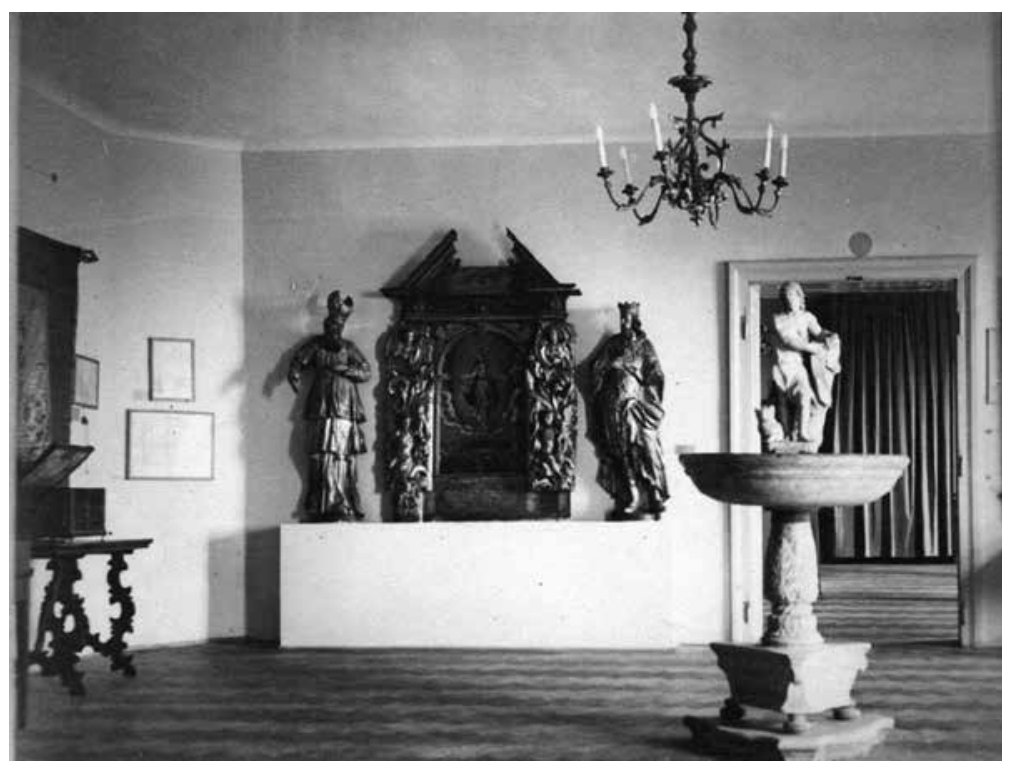

6. Muzej grada Zagreba, stalni postav u Opatičkoj 20, detalj Dvorane VII, prije demontiranja 1959. godine (MGZ, inv. ozn. F-158)

Municipal Museum of Zagreb, permanent exhibition at Opatička No. 20, detail of Hall VII before the dismantling in 1959 


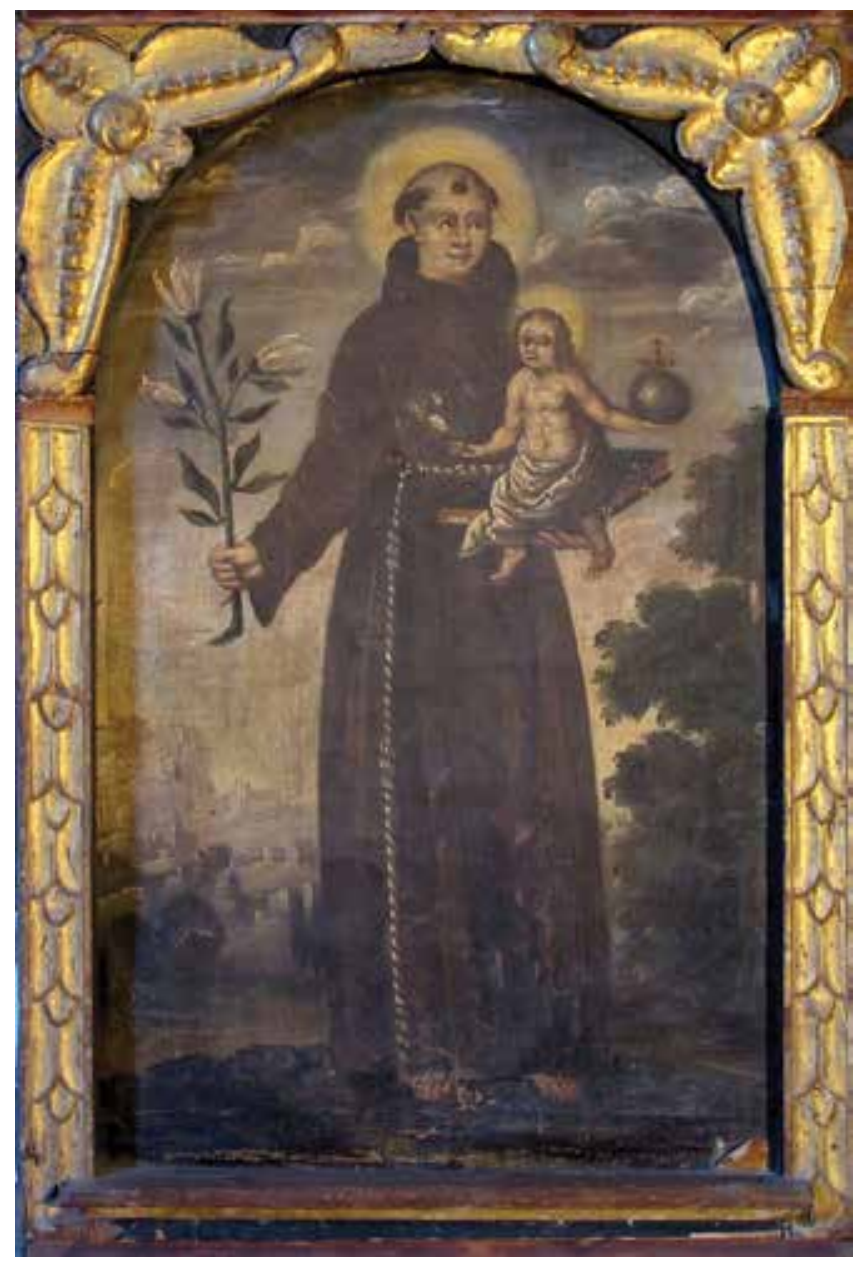

7. Muzej grada Zagreba, slika Sv. Antun Padovanski, neznani autor, 17. stoljeće (MGZ 359)

Municipal Museum of Zagreb, St Anthony of Padua, anonymous painter, $17^{\text {th }}$ century

nužan za nedvojbenu identifikaciju. ${ }^{18}$ Osobito su dragocjene sačuvane arhivske fotografije stalnog postava u dokumentaciji Muzeja grada Zagreba, gdje se nalazi najraniji snimak (sl. 5) stalnog postava iz 1945. godine, kada je oltar bio smješten u Opatičkoj 8, pri čemu su mu u neposrednom susjedstvu izložene dvije slike također podrijetlom iz Kuča (slika Sveti Antun Padovanski (sl. 7) i slika Sveti Nikola). ${ }^{19} \mathrm{U}$ idućem postavu u Opatičkoj 20 od 1946. do 1970-ih godina i ta se povijesna asocijacija izgubila. Uz njega su tada bile izložene kiparske figure Kralja Davida (MGZ-375) i Proroka Izaije (MGZ-376) koje su mu svojom visinom od $146 \mathrm{~cm}$, odnosno $160 \mathrm{~cm}$, dosezale sve do vijenca (sl. 6). ${ }^{20}$ Budući da te skulpture neznanoga autora iz 1755 . godine potječu s bočnoga oltara Presvetoga Tijela Kristovog iz župne crkve sv. Marka u Zagrebu, razlog njihovom uparivanju u muzejskom prostoru bio je prije svega estetske prirode..$^{21}$ Štoviše, na fotografiji koju je prema naputku Artura Schneidera snimio Ljudevit Griesbach u Muzeju 1937. godine (sl. 8), ${ }^{22}$ novokreiranoj oltarnoj cjelini bile su u jednom trenutku pridodane još i tri drvorezbarene polikromirane skulpture: Bog Otac (MGZ-2615, v. $69 \mathrm{~cm}$ ), dva mala poklekla putta (MGZ-2701, MGZ-2703, v. $34 \mathrm{~cm}$ ) i rezbarena knjiga (koju

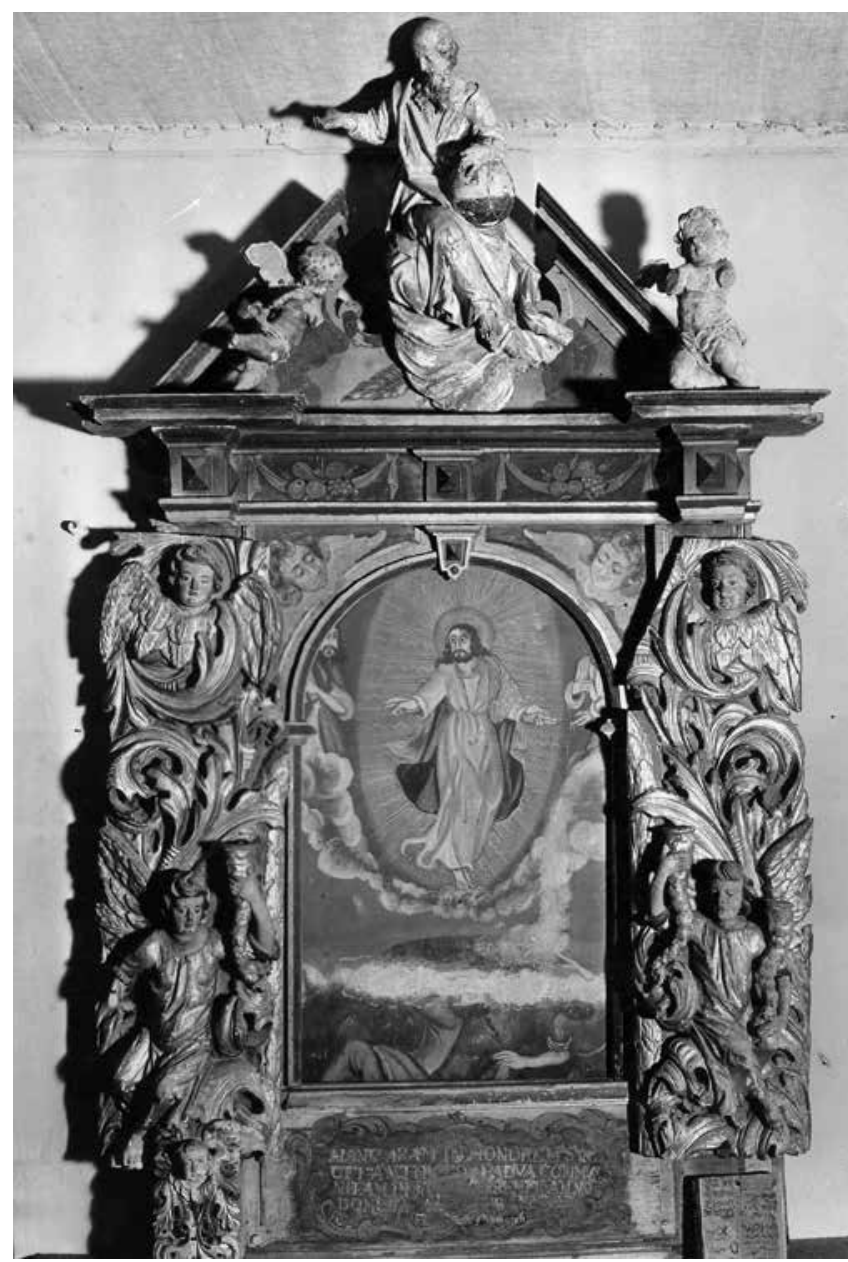

8. Oltar Preobraženja Gospodinova u Muzeju grada Zagreba (foto: Lj. Griesbach, 1937., Schneiderov fotografijski arhiv, SFA 1084; presnimak u Fototečnoj službi MK pod inv. br. 13949; neg. II-15351)

Altar of the Transfiguration, Municipal Museum of Zagreb

nismo zatekli u depou Muzeja). ${ }^{23}$ Ipak, čini se da je tako složena cjelina služila samo za jednokratnu potrebu fotografskog dokumentiranja. ${ }^{24}$

Posljednjih je desetljeća, naime od izrade novoga stalnog postava od 1972. do 1975. godine pa sve do danas, ${ }^{25}$ oltar bio pohranjen $u$ depou jer nije izravno povezan s prošlošću grada Zagreba te nije bilo naznaka za buduću njegovu prezentaciju u muzejskom postavu. ${ }^{26} \mathrm{Na}$ inicijativu Konzervatorskog odjela u Zagrebu i Župe Pohoda Marijina u Vukovini za povratom oltara, Muzej grada Zagreba odgovorio je pozitivno podržavši uzimanje iz fundusa i povrat vlasniku, za što je Hrvatsko muzejsko vijeće i Ministarstvo kulture dalo svoju suglasnost 17. prosinca 2014. godine. ${ }^{27}$ Time je usuglašena i uspješno provedena demuzealizacija oltara, što je pionirski pothvat na prostoru kontinentalne Hrvatske. Demuzealizacija je redovito kontroverzna tema, i to ne samo u lokalnim okvirima nego i u globalnim, prvenstveno zbog različitih viđenja zainteresiranih grupacija $\mathrm{u}$ odnosu na pravo raspolaganja umjetninom, ${ }^{28}$ stoga se pitanje očuvanja same umjetnine često nađe na margini rasprava. Prva demuzealizacija u Hrvatskoj izvršena je 2000. 
godine kada je raspelo Blaža Jurjeva Trogiranina vraćeno u katedralu u Trogiru za koju je i bilo rađeno. ${ }^{29}$ Treba istaknuti da je s konzervatorskog i restauratorskog stanovišta svako premještanje umjetnine rizično, zbog čega se nastoje čim točnije procijeniti potencijalne opasnosti i koristi. Sretna je okolnost što povrat oltara u Kuče nije zahtijevao nikakvu preinaku kapele za koju nikada nisu bili nabavljeni bočni oltari, nego samo pojedinačne svetačke skulpture tirolske provenijencije. Nasuprot demuzealizaciji koja ne obiluje brojnim primjerima, slučajevi resakralizacije razmjerno su češći. Nerijetko se dešava da su umjetnine uklonjene iz crkvenih prostora zbog raznoraznih razloga, poput oronulosti, promjene ukusa, ukidanja liturgijske funkcije i slično. Mnoge su umjetnine nepovratno uništene, no neke su ipak spašene i vraćene u crkveno okruženje. Vrijedi istaknuti uspješne primjere resakralizacije, od kojih na području sjeverozapadne Hrvatske izdvajamo vraćanje propovjedaonica u župnu crkvu sv. Jurja u Plešivici, u župnu crkvu Bezgrešnog Začeća Marijina u Maču te u župnu crkvu Presvetoga Trojstva u Svetoj Nedelji, ili pak relikvijara u župnu crkvu Uznesenja Marijina u Kloštru Ivaniću. Među rijetkim primjerima široke i temeljite pripreme može se spomenuti i slučaj preuređenja svetišta i resakralizacije baroknoga glavnog oltara u dubrovačkoj katedrali. Kao doprinos sagledavanju teme organiziran je 17. veljače 2012. godine Okrugli stol o pitanju glavnog oltara dubrovačke Stolne crkve Gospe Velike, uz sudjelovanje zainteresiranih strana i velikog broja relevantnih stručnjaka koji su raspravljali o temi i donijeli zaključke koji su u konačnici odredili smjer obnove. ${ }^{30}$

\section{Arhivska i restauratorska istraživanja}

Nakon 106 godina izbivanja oltar je vraćen u liturgijsku funkciju u kapelu sv. Fabijana i Sebastijana u Kučama. Međutim, preseljenje u muzej i povratak nazad u kapelu nisu njegova jedina premještanja. Povijesni slijed promjena njegovih adresa otkriva se iz usporednog iščitavanja zapisa kanonskih pohoda i gradiva same umjetnine. Kao što je rečeno, u Muzeju je oltar dobio titular Preobraženja Gospodinova spajanjem $\mathrm{s}$ istoimenom, ali kasnijom oltarnom palom iz kapele, no natpis na predeli (sl. 9) otkriva raniju posvetu svetom Antunu Padovanskom:

\section{HANC ARAM IN HONOREM SAN \\ CTI ANTONII DE PADVA COMMV \\ NITAM IN R... .R.NIT ANNO \\ DOMINI ......(M PARO)CHO \\ ...ich}

Kada je oltar posvećen svetom Antunu iz toga natpisa ne saznajemo, jer su i godina i ime župnika oštećeni. Natpis se nalazi na naknadnom crnom premazu kojim je pokriven još stariji te znatno oštećeniji natpis, najvjerojatnije izvorno ispisan na svijetloplavoj podlozi, ${ }^{31}$ od kojeg se na rendgenskom snimku (sl. 10) može pročitati (u sredini se nalazi tondo u kojem je moguće bio grb, pa se tekst u tom dijelu prekida):

\section{Ad Lavde(M)D(eI) \\ O.R...OTEM \\ EtS. Magdalenae \\ $\operatorname{EgR}(\mathrm{E}) \mathrm{G}(\mathrm{I}) \mathrm{V}(\mathrm{s})$ \\ Fieri FeCIT \\ (I)OAN: SKERLEC $(\mathrm{z})^{32}$}

Iz toga, starijeg izvornog natpisa saznajemo dragocjene podatke. Oltar je, dakle, prvotno bio posvećen Mariji Magdaleni. Dok kapela u Kučama nije imala oltar svete Marije Magdalene, takav je oltar postojao u staroj župnoj crkvi svetog Jurja u Starom Čiču, zapuštenoj potkraj 18. stoljeća i porušenoj nakon 1805. godine, kada je hodočasnička crkva u Vukovini već bila preuzela ulogu župne. ${ }^{33}$ Natpis također otkriva i ime naručitelja, a moguće i donatora ${ }^{34}$ oltara, a to je zagrebački kanonik Ioannes Skerlecz (Ivan Škrlec, $† 1659$.). ${ }^{35}$ Arhivska vrela navode da je u Starom Čiču imao kuću, a

9. Oltar Preobraženja Gospodinova, natpis na predeli (foto: M. Braun, 2016., Fototeka HRZ-a)

Altar of the Transfiguration, inscription on the predella

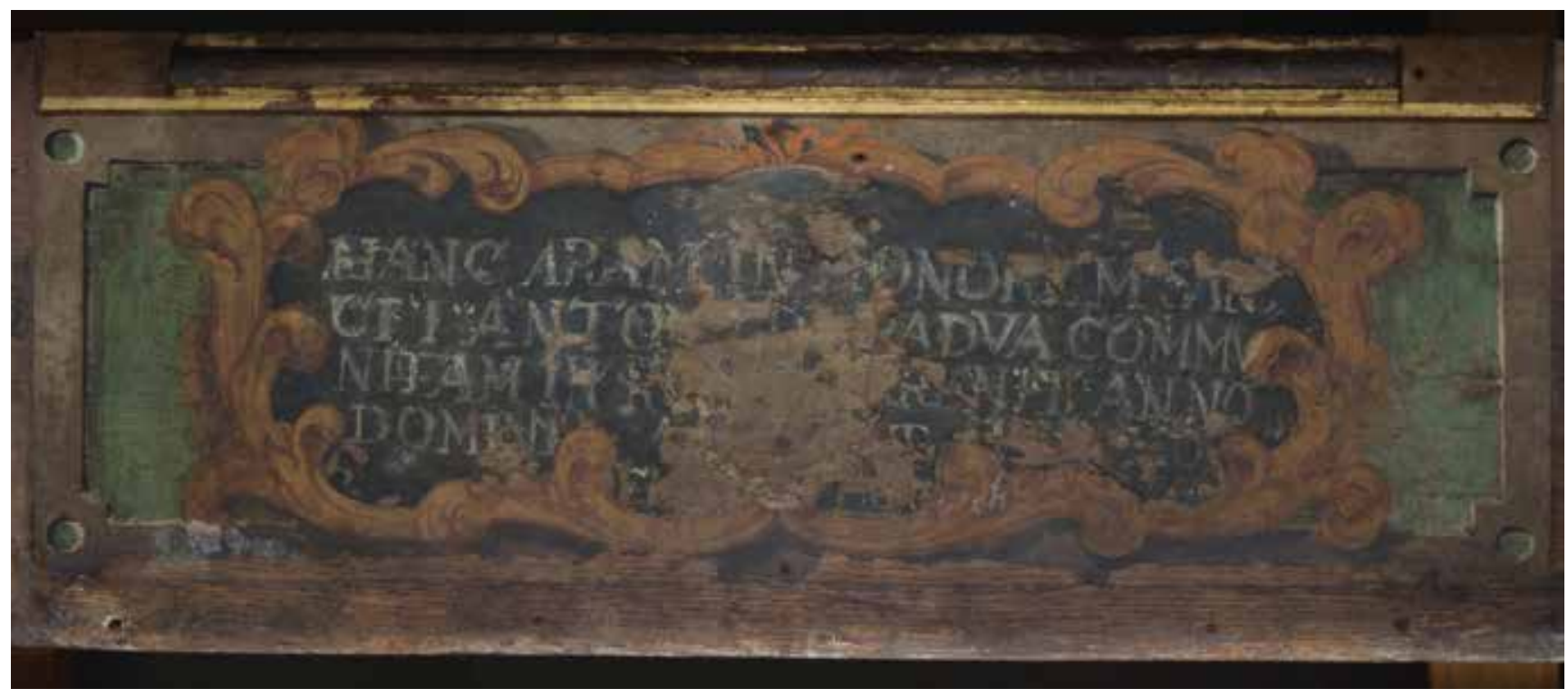




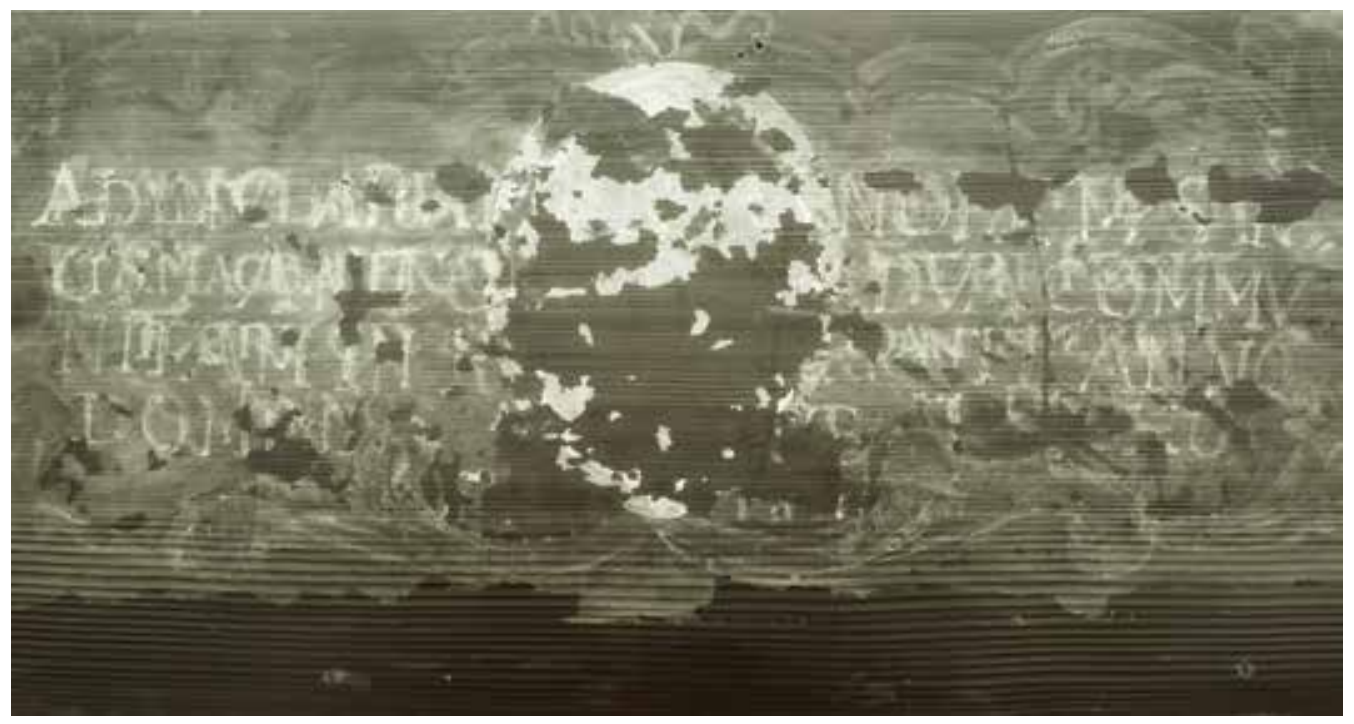

10. Oltar Preobraženja Gospodinova, rendgenski snimak natpisa (foto: M. Braun, 2016., Fototeka HRZ-a) Altar of the Transfiguration, $x$-ray shot of the inscription

majka mu se zvala Magdalena Pogledić i bila je rodom iz obližnjeg Kurilovca, ${ }^{36}$ pa bi prvotna posveta oltara mogla biti povezana s njezinim imenom. Biografski podaci o naručitelju upotpunjuju se sa zapisima kanonskih pohoda koji šturo 1642. godine izvješćuju da župna crkva posjeduje tri oltara, dok ih prilikom pohoda 1649. poimence navode, nabrajajući tako da je na strani Poslanice postavljen oltar sv. Marije Magdalene ${ }^{37}$ Izvjesno je, dakle, da je oltar dao podići Škrlec u tom razdoblju, moguće kao čin zahvale za svoja napredovanja u službi, s obzirom na to da je 1642. godine prisegao za kolegij u Beču, a 1648. postao zagrebački kanonik..$^{38}$ Istovremeno, kapela u Kučama posjeduje samo glavni oltar. Tek neznatno podrobnije se oltar sv. Marije Magdalene prvi put opisuje 1678. godine kada vizitator bilježi da je izrezbaren, oslikan i »malo pozlaćen «, sa slikom svetice na platnu. ${ }^{39}$ Međutim, već 1685 . godine vizitator kapele u Kučama izvješćuje da je za svotu od tri rajnske forinte i 40 krajcara »kupljen jedan stari oltar od župne crkve«, no bez detaljnije identifikacije..$^{40}$ Župnik Florijan Pavlinićc ${ }^{41} \mathrm{u}$ to je vrijeme pokrenuo obnovu župne crkve za koju su nabavljena dva nova bočna oltara sv. Franje Ksaverskog i sv. Marije Magdalene oporučnim darovima pokojnoga Stjepana Katulića, župnika u Martijancu, a rodom iz Starog Čiča. ${ }^{42}$ U opisu iz 1692. godine, a osobito u nešto sadržajnijem iz 1695. godine, novopostavljeni oltar sv. Marije Magdalene opisuje se kao dvokatni, sa središnjom slikom na platnu s prikazom svetice između stupova i kipova sv. Florijana i Udalrika. $\mathrm{Na}$ atici je središnja slika na platnu s prikazom svete Katarine između stupova i kipova svetih Augustina i Ambrozija, a na samome vrhu uzvišen stoji kip svetog Mihaela. ${ }^{43}$ Jasno je da ovaj opis ne odgovara oltaru u Muzeju, što ukazuje da je upravo oltar sv. Marije Magdalene taj stari oltar koji je kupljen od župne crkve. Titular tog oltara vizitator izrijekom spominje tek 1692. godine nabrojavši u kapeli dva oltara, glavni i bočni oltar sv. Antuna Padovanskog. ${ }^{44}$ Preseljenjem na novu lokaciju u kapelu u Kučama dotadašnji oltar sv. Marije Magdalene posvećen je novom zaštitniku, u narodu omiljenom svetom Antunu Padovanskom.

Je li slika Svetog Antuna Padovanskog (sl. 7, MGZ-359) koju su Laszowski i Barlè zatekli u kapeli, a koja se čuva u Muzeju grada Zagreba, pripadala tom oltaru? Naime, rozete s hrskavicom i žljebasto oblikovani lisnati nizovi približno datiraju okvir slike u posljednju četvrtinu 17. stoljeća te se lako može raditi o izvornoj slici s oltara svetog Antuna iz 1692. godine. Ipak, s obzirom na manje dimenzije od otvora oltara Preobraženja Gospodinova, kao i s obzirom na činjenicu da ima sačuvan vlastiti ukrasni okvir, nije vjerojatno da je u ijednom trenutku činila cjelinu s današnjim oltarom Preobraženja. ${ }^{45}$

\section{Konstrukcija oltara}

Premda je oltara iz prve polovice 17. stoljeća u kontinentalnoj Hrvatskoj sačuvano tek nekoliko, i to je dovoljno da se primijeti koliko se koncept njihove gradnje razlikuje od one oltara koji će nastupiti nekoliko desetljeća poslije. ${ }^{46} \mathrm{I}$ oltar Preobraženja Gospodinova slijedi provjerena rješenja retabala građenih u prvoj polovini 17. stoljeća, naslanjajući se na renesansnu tradiciju jednostavne arhitektonske kompozicije stroge tektonike, mahom zasnovane na motivu edikule sa stupovima koji omeđuju oltarnu palu, te redovito bez skulpturalnih elemenata uz tek skromno zastupljenu ornamentiku. ${ }^{47}$ Retabl je izrađen od drva hrasta ${ }^{48}$ koje je u Turopolju bilo lako dostupno i dobre kakvoće. To je drvo nepogodno za rezbarenje, ali je čvrsto, otporno i trajno te kao takvo pogodno za predmete jednostavne, plošne obrade. Predela je jednostavna, plitka i plošna, a vjerojatno je na oba kraja bila istaknuta, danas izgubljenim, postamentima stupova.

Premda ni stupovi nisu sačuvani, tragovi obojenja i ostaci kamenčića uz rubove jasno pokazuju o kakvom se, za naše područje iznimno rijetkom, oblikovnom i tehnološkom 


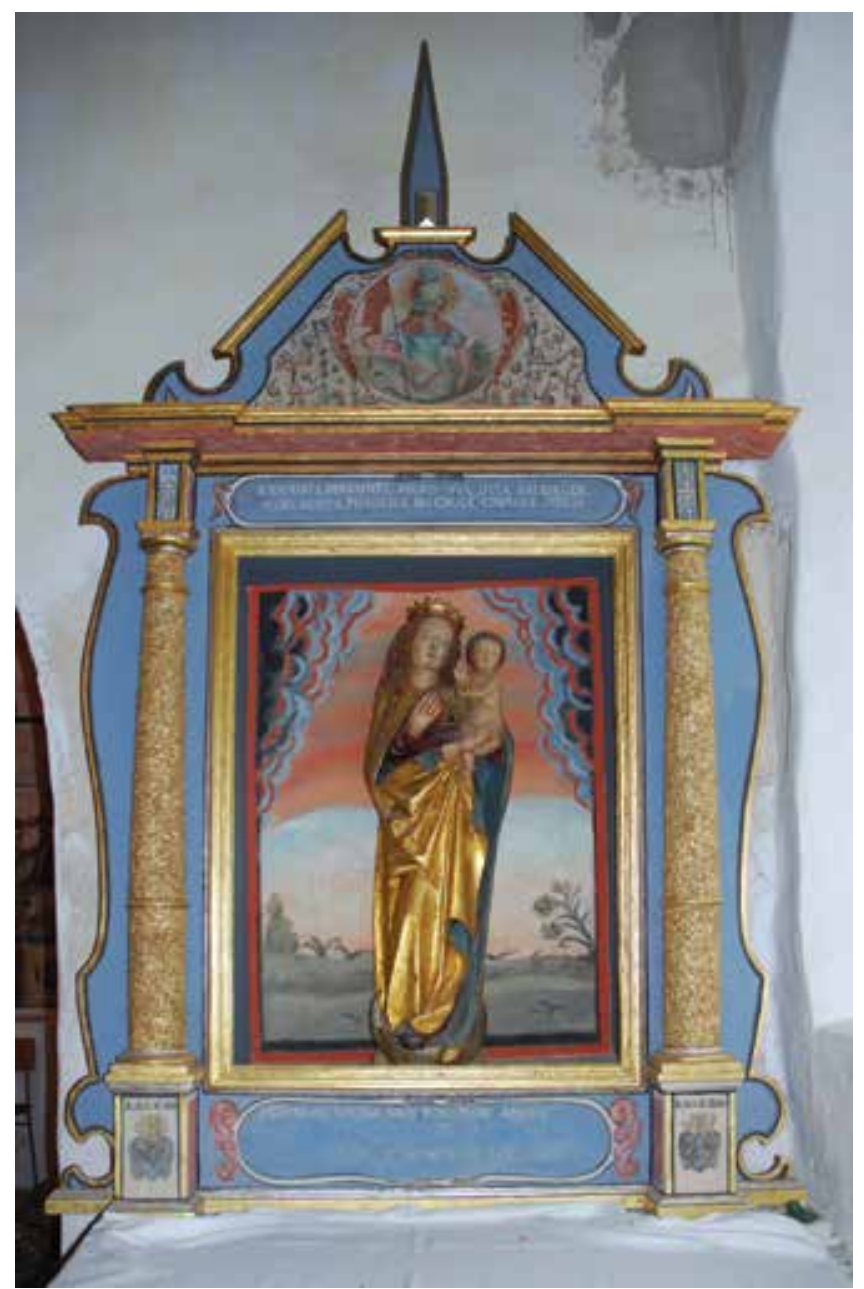

11. Martinščina, kapela sv. Martina, bočni oltar Majke Božje (foto: K. Škarić, 2011.)

Martinščina, chapel of St Martin, side altar of Our Lady

rješenju radilo. Stupovi su bili ukrašeni tehnikom koja se, po analogiji s uzorom u zlatarstvu, naziva granulacijom. U zlatarstvu se granulacijom naziva tehnika nanošenja zrnaca zlata na površinu metala čime se postiže ukrasna hrapava površina. U polikromiji se radi o lijepljenju šljunka ili krupnog pijeska na površinu drva, koja se potom preparira i pozlaćuje. Njemački naziv za ovu tehniku je Sandelung, ${ }^{49} \mathrm{pa}$ bismo je hrvatski mogli nazvati i ošljunčenje ili opjeskarenje. Stup bi zbog svoje primarne uloge nosača trebao asocirati na čvrstoću, ali umjesto toga on postaje titrava, gotovo amorfna gruda nejasnih granica koja difuzno rasipa svjetlost.

Upravo zbog svoje bizarnosti i antiklasičnog karaktera, tehnika je bila omiljena ćudljivom ukusu sedamnaestog stoljeća, ali je ta moda bila kratkoga daha. Granulacija ni s tehničke strane nije trajna: amorfnu masu relativno teškog anorganskog materijala na okupu privremeno drži organsko ljepilo i tanka kora polikromacije, pa je ta tehnika i fizički sklona eroziji. Sipkost materijala i prolaznost mode uzrokom su što je takvih stupova sačuvano vrlo malo. Sačuvani primjeri u kontinentalnoj Hrvatskoj kasnijeg su datuma, poput stupova na bočnom oltaru Majke Božje u kapeli sv. Martina u Martinščini iz 1660-ih godina (sl. 11) i na bočnom oltaru Krštenja Kristova u kapeli

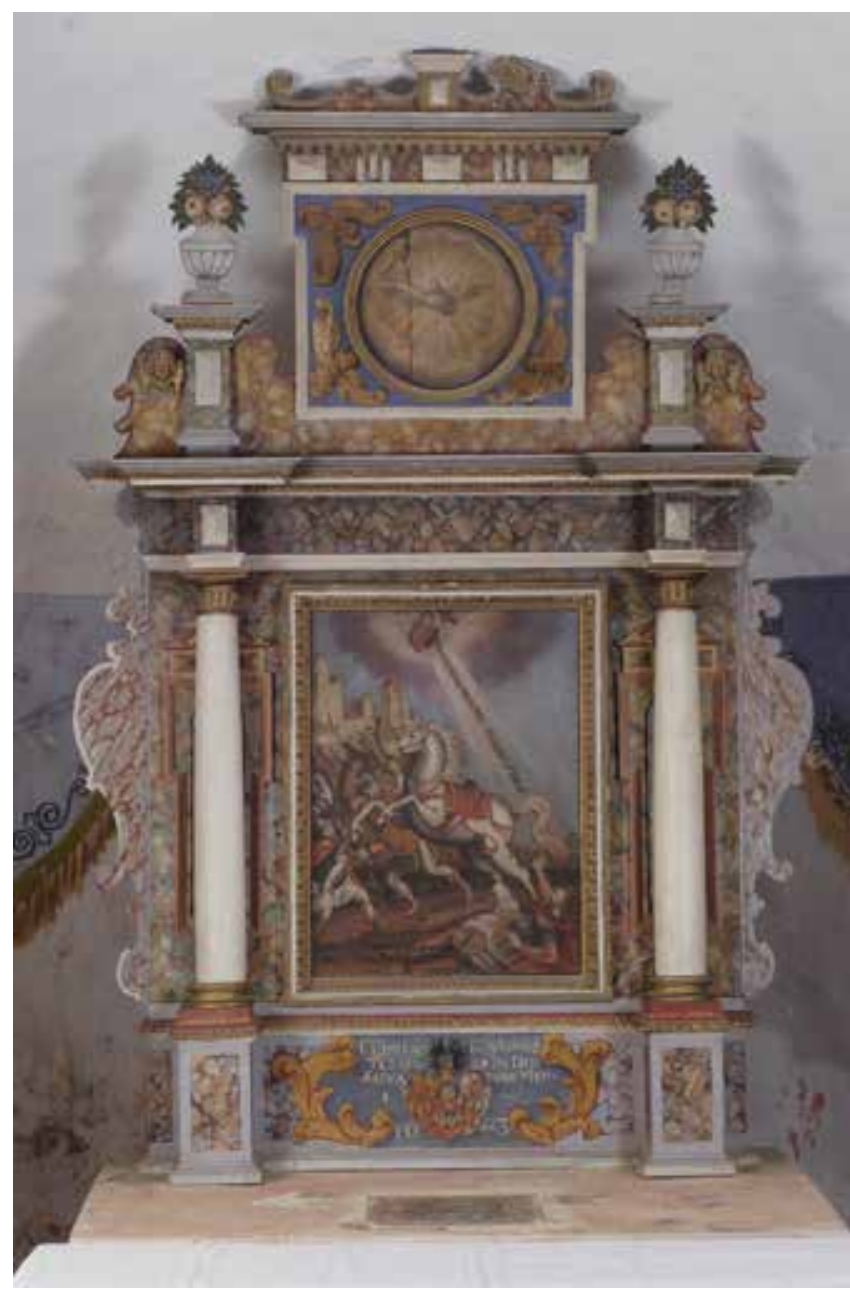

12. Pavlovčani, kapela sv. Pavla, glavni oltar (foto: N. Oštarijaš, 2011., Fototeka HRZ-a)

Pavlovčani, chapel of St Paul, high altar

sv. Barbare u Brestu Pokupskom, nastalom nešto prije 1696. godine. Oltar u Kučama, izvorno iz župne crkve u Starom Čiču, predstavlja najraniji potvrđeni primjer toga rijetkog oblikovnog i tehnološkog rješenja na tom prostoru.

Postoji nedoumica oko obojenja granuliranih stupova. Komparativna građa iz susjednih regija Austrije i Njemačke navode na zaključak da su takvi 'ošljunčeni' stupovi uvijek bili u potpunosti pozlaćeni, međutim naša su saznanja drugačija. Premda su stupovi u Martinščini danas pozlaćeni, zapis kanonske vizitacije iz 1729. godine opisuje ih modrima i samo manjim dijelom pozlaćenima. ${ }^{50} \mathrm{Na}$ oltaru iz Bresta Pokupskog granulacija je obojena tamnozeleno, a bilješke kanonskih vizitacija iz 1696. i 1729. godine podjednako tvrde da su stupovi in formam lapideam bili posrebreni i (samo dijelom) pozlaćeni. ${ }^{51}$

Oltarna krila se nisu sačuvala, ali prema komparativnoj građi može se pretpostaviti da se radilo o jednostavnim daskama izrezanim u obrisu (sl. 13) koje su onda bile bogato polikromirane. ${ }^{52}$ Takva rješenja nalazimo na najstarijim drvenim oltarima u kontinentalnoj Hrvatskoj, na oltaru sv. Lovre u Starom gradu Varaždinu iz 1617. godine i na bočnom oltaru Svete Obitelji u kapeli Uznesenja Blažene Djevice Marije u 


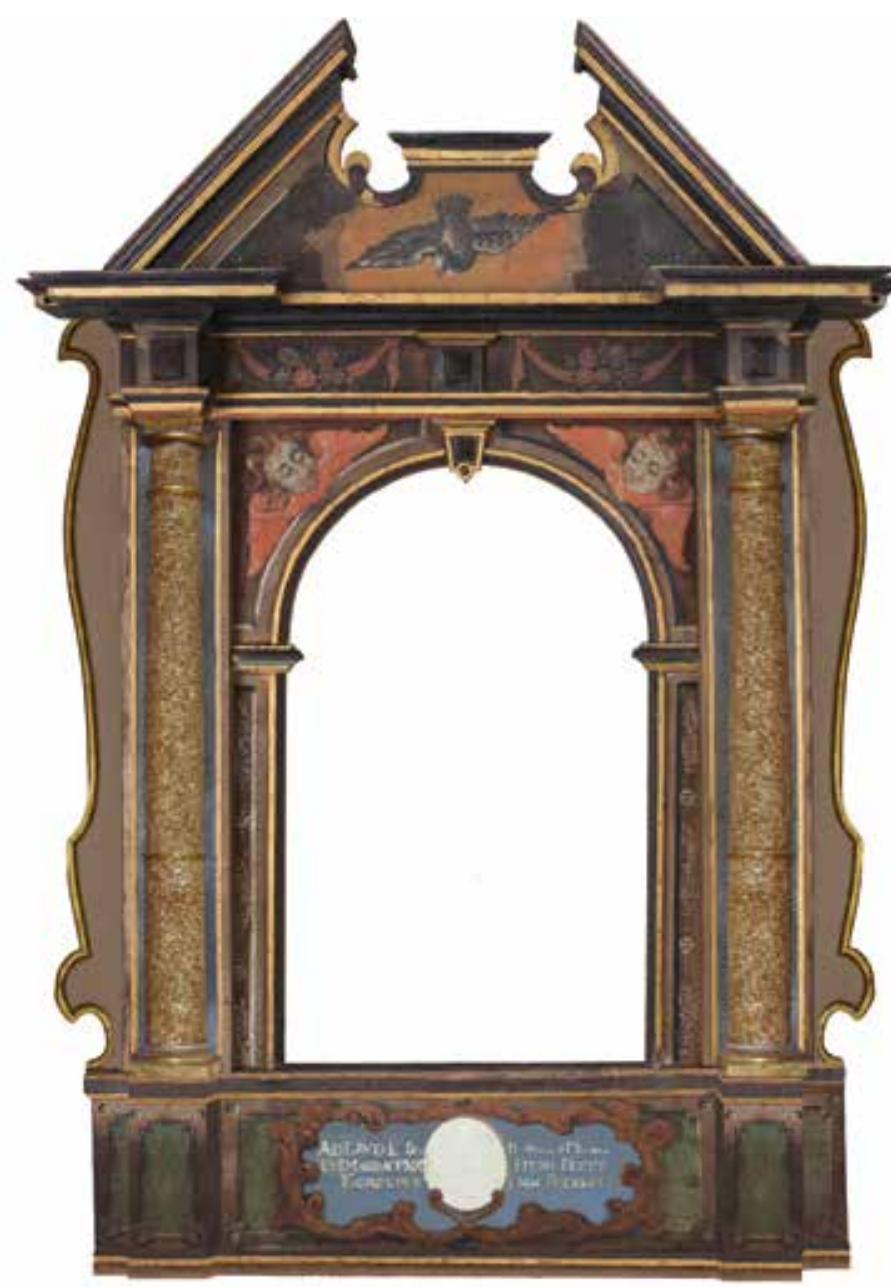

13. Simulacija prvotnog izgleda oltara sv. Marije Magdalene iz negdašnje župne crkve u Starom Čiču (izradila Ksenija Skarić)

Simulation of the original appearance of the altar of St Mary Magdalene from the former parish church in Staro Čiče

Gornjem Tkalcu iz 1628. godine. Takva krila nalazimo i na kasnijim, ali jednostavno zasnovanim oltarima, poput glavnog oltara svetog Pavla u kapeli sv. Pavla u Pavlovčanima iz 1643. godine (sl. 12) i bočnog oltara Majke Božje u

14. Oltar Preobraženja Gospodinova, detalj atike (foto: G. Tomljenović, 2017., Fototeka HRZ-a)

Altar of the Transfiguration, detail of the attic kapeli sv. Martina u Martinščini iz 1660-ih (sl. 11). Ukrasna plošna krila, međutim, nisu bila namijenjena samo oltarnoj arhitekturi, nego su primjenjivana i na drugim predmetima crkvenog namještaja, poput, na primjer, sakristijskog ormara iz oko 1652. godine iz Fratrovaca, a danas pohranjenog u Muzeju u Ozlju.

Jednostavna trabeacija nosi prekinuti trokutasti zabat kojemu je središnji dio odrezan i uklonjen, a vjerojatno je predstavljao dekorativni arhitektonski element ili možda kartušu s monogramom..$^{53}$ Ornamentika je vrlo skromno zastupljena, a danas su sačuvane samo prizmatične profilacije, odnosno motivi dijamanta raspoređeni u zoni trabeacije i manji dijamantni ukras u tjemenu lučnog zaključka otvora za oltarnu palu. Taj motiv dijamanta ili dragulja nalazi se i na drugim navedenim oltarima prve polovine 17. stoljeća $\mathrm{u}$ kontinentalnoj Hrvatskoj. ${ }^{54}$ Bio je to omiljen element $\mathrm{u}$ ornamentalnom repertoaru toga vremena, zajedno s motivima okovlja, svitaka i drugih, ${ }^{55}$ koji su se popularizirali i proširili diljem Srednje Europe putem grafičkih predložaka na prijelazu stoljeća. Među njima se osobito ističu invencije objavljene u priručnicima za stolare, arhitekte, kipare i druge, primjerice, nizozemskog arhitekta, slikara i grafičara Hans Vredemana de Vriesa (Leeuwarden, oko 1527. - Antwerpen (?), oko 1607.), ${ }^{56}$ zatim njemačkoga slikara, teoretičara i grafičara Wendela Dietterlina Starijeg (Pfullendorf, oko 1550. - Strasbourg, 1599.), ${ }^{57}$ pod čijim je utjecajem bio njegov sunarodnjak grafičar i slikar Daniel Meyer Stariji, ${ }^{58}$ ili pak švicarskoga bakroresca Gabriela Krammera (Zürich, 1564. - ?, 1611.)..$^{59}$

\section{Polikromija}

Nedostatak rezbarije na oltarnim rješenjima prve polovine 17. stoljeća obilno nadoknađuje polikromija. Raspon naslikanih ukrasa kreće se od jednobojnih, posrebrenih i pozlaćenih površina sa i bez lazura preko marmorizacija do naslikanih arhitektonskih elemenata kod kojih iluziju trodimenzionalnosti pojačava prikaz obasjane i zasjenjene strane, naslikanih vitica, girlandi i fruktona, bordura, dijamantnih ukrasa, gumba i ukrasnih nizova. Višebojno se izmjenjuje sa slikanim imitacijama crteža. S obzirom na prisutnost figurativnih prikaza, ne postoji oštra razdjelnica prema štafelajnom slikarstvu.

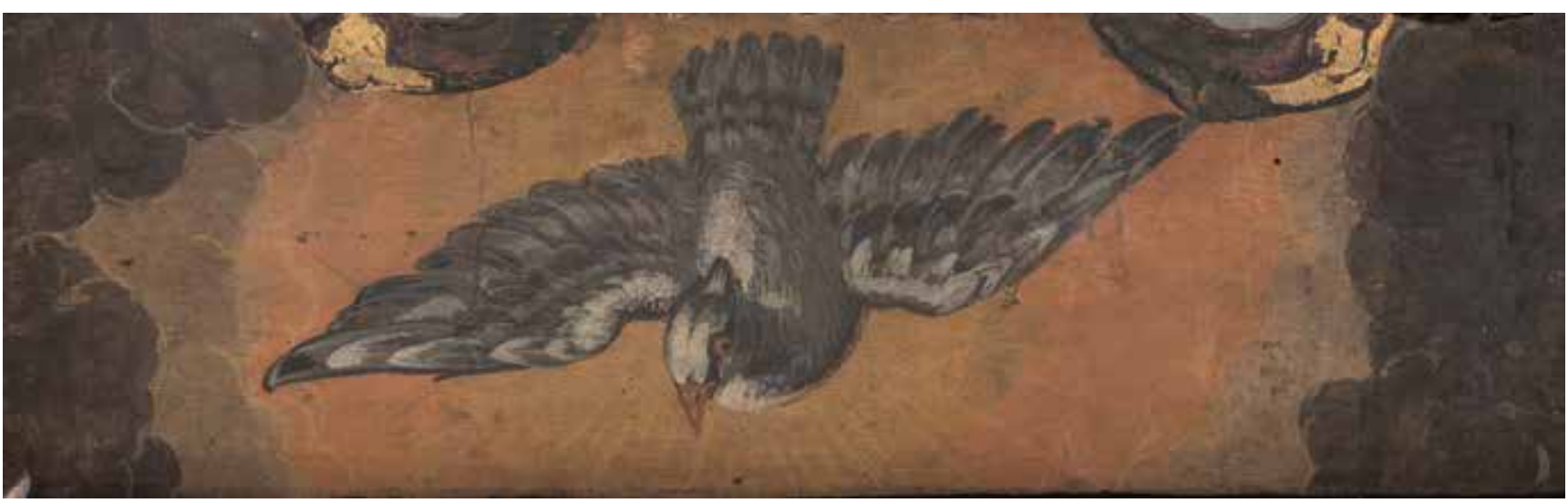




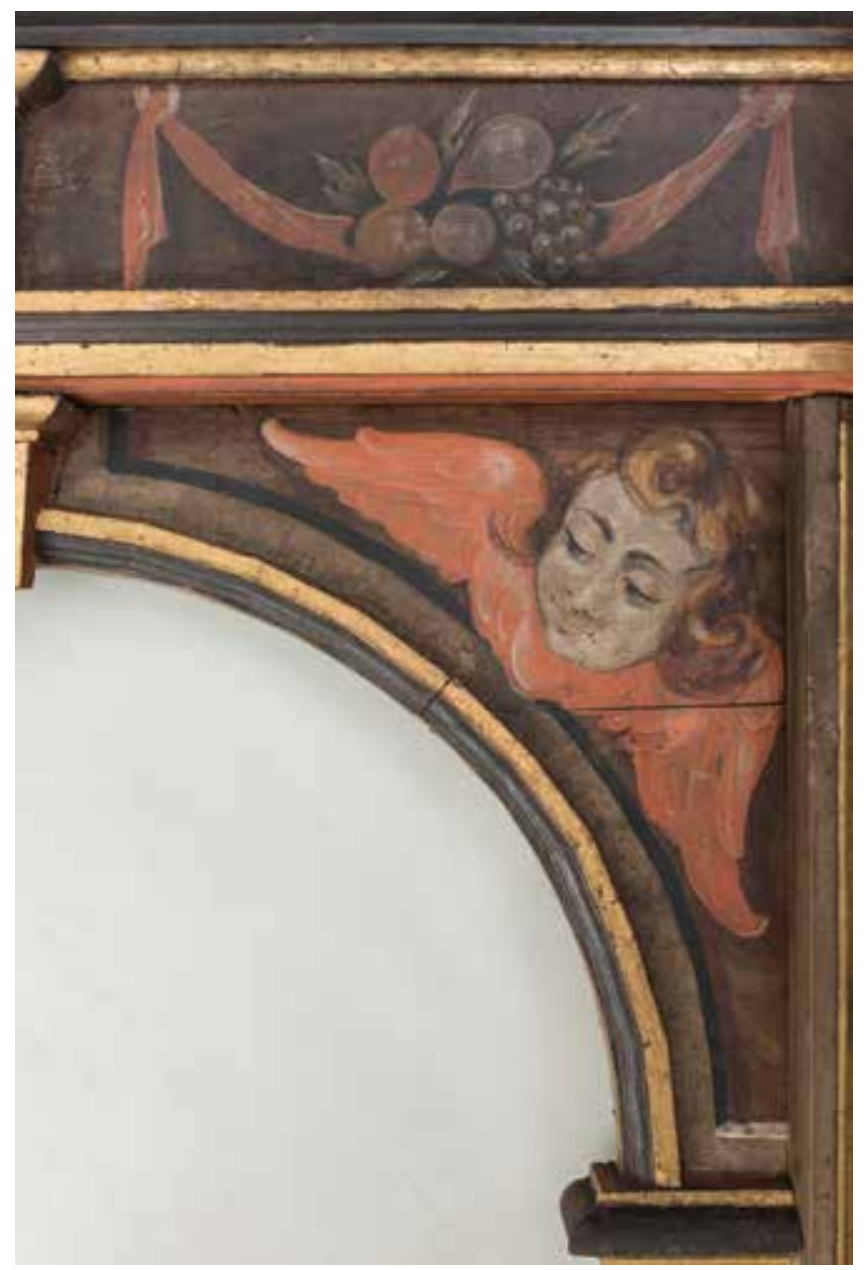

15. Oltar Preobraženja Gospodinova, detalj retabla (foto: G. Tomljenović, 2017., Fototeka HRZ-a)

Altar of the Transfiguration, detail of the retable

Prvotna polikromija oltara Preobraženja Gospodinova, odnosno oltara svete Marije Magdalene, ostala je, uz manja, djelomična preslikavanja, sačuvana i vidljiva do danas. Značajke prve polovice 17. stoljeća uočljive su već na prvi pogled: figurativni prikazi izmjenjuju se s jednobojnim vinjetama. Figurativni oslik ispunio je sve slobodne veće plohe: prizor s golubicom Duha Svetoga ispunio je ravnu plohu atike (sl. 14), krilate anđeoske glave (sl. 15) zauzimaju kutove oko lučnog dijela slike gotovo u potpunosti, a girlande $s$ voćem friz. Manje plohe - uske trake uz sliku, kutovi atike i njezina donja ploha - ispunjeni su vitičastim ukrasom koji su, u skladu s ostalim primjerima iz 17. stoljeća, naslikani svjetlijom bojom na tamnijoj površini. ${ }^{60}$ Naizgled pravilne, kao da su izvedene uz pomoć šablone, zapravo su naslikane prostoručno bez pomagala. Vrlo sličan način oslikavanja donje plohe atike nalazimo, primjerice, na oltaru sv. Pavla
Pustinjaka (negdašnjem oltaru svete Notburge) iz 1631. godine u pavlinskoj crkvi u Sveticama.

Pored tih osobina polikromije, koje se mogu naći tijekom cijelog 17. stoljeća, posebnost su najranijih oltara bez rezbarije naslikani arhitektonski ukras kojim se pokušava iluzionirati nepostojeća treća dimenzija ravnih dijelova oltara i evocirati plastični ornament. ${ }^{61} \mathrm{Na}$ oltaru Preobraženja Gospodinova ukrasi koji evociraju ornament okovlja naslikani su tako da se čini da je izvor svjetla zdesna. ${ }^{62}$

Samo manji dio slikanog ukrasa danas je preslikan. Radi se prvenstveno o dijelovima koji su bili posrebreni, ali su poslije oksidirali i potamnjeli, što je mogući razlog zbog kojeg su prebojeni crno. Tako se ispod crnog premaza na profilacijama zabata nazire jajčano-strelični niz naslikan lazurama na posrebrenju.

Natpis na predeli ovjenčan je žuto-narančastim akantovim lišćem zadebljanih, zavijenih vrhova (sl. 9), a koji pripada izvornom slikanom sloju. Vrijedi istaknuti da je taj lisnati okvir gotovo istovjetan okviru akantova lista koji okružuje natpis na predeli glavnoga oltara u kapeli sv. Pavla u Pavlovčanima iz 1643. godine (sl. 12), što navodi na zaključak da su se radionice vjerojatno služile istim ili sličnim predlošcima za ornamentalne ukrase. O kojim je to radionicama riječ, međutim, nije moguće utvrditi. S obzirom na manjak komparativne građe te slabo očuvane ugovore između naručitelja i izvođača, računa ili srodnih arhivskih dokumenata u istraživanjima baštine kontinentalne Hrvatske 17. stoljeća koji bi nesumnjivo potvrdili identitet majstora, i na ovom ćemo primjeru ostati u sferi nagađanja i po pitanju slikara i po pitanju stolarske radionice. Iz vrsnoće slikarskog poteza kojim je naslikana golubica Duha Svetoga na atici u vješto riješenom perspektivnom skraćenju, kao i anđeoske glavice u kutovima s nježno osjenčanim crtama lica i mekim uvojcima kose, naslućuje se vješta ruka neznanoga slikara kojemu se obratio naručitelj oltara Ivan Škrlec. Kao zagrebački kanonik i s ranije uspostavljenim vezama s Bečkim kolegijem, očito je bio dobro upoznat sa suvremenim umjetničkim htijenjima, a njegov ugled i profinjeni naručiteljski ukus čine se zaslužnim za kvalitetu slikarskog umijeća koje premašuje okvire lokalne razine. Ostaje otvoreno je li se obratio domaćoj radionici, moguće kojoj na Kaptolu, ili je oltar dopremljen iz udaljenih regija poput Štajerske ili Ljubljane s kojima su već bile ostvarene uspješne umjetničke suradnje za potrebe opremanja zagrebačkih crkvi. ${ }^{63}$

Oltar Preobraženja Gospodinova, odnosno svetog Antuna Padovanskog, odnosno svete Marije Magdalene, nakon stoljetnog se izbivanja vratio u turopoljski kraj. Premda odavno više nema njegove izvorne crkve u Starom Čiču, a niti prethodne drvene kapele u Kučama, oltar je ponovno smješten u sakralnom ambijentu i vraćen u liturgijsku funkciju za koju je, prije svega, i bio izrađen. 


\section{Bilješke}

1

Najstariji sačuvani oltar iz 17. stoljeća u kontinentalnoj Hrvatskoj potječe iz 1617. godine te se nalazi u dvorskoj kapelici Staroga grada Varaždina. Vidi: ANĐELA HORVAT, Između gotike i baroka - Umjetnost kontinentalnog dijela Hrvatske od oko 1500. do oko 1700., Zagreb, 1975., 390; LJERKA ŠIMUNIĆ, Oltar sv. Lovre u kapeli varaždinskog Starog grada, u: Radovi Zavoda za znanstveni rad HAZU Varaždin, 6-7 (1994.), 43-49; SANJA CVETNIĆ, Umjetnička baština Varaždina od renesanse do klasicizma, u: 800 godina slobodnog kraljevskog grada Varaždina 1209.-2009. Zbornik radova sa Znanstvenog skupa održanog 3. i 4. prosinca 2009., (ur.) Miroslav Šicel, Varaždin, 2009., 568.

2

Oltar je restauriran tijekom 2016. i 2017. godine na poticaj Martine Ožanić iz Konzervatorskog odjela u Zagrebu. Konzervatorsko-restauratorske radove na retablu vodila je Ksenija Škarić, a na oltarnoj slici Slobodan Radić.

3

SANJA CVETNIĆ, Likovna i graditeljska baština Župe Pohoda Blažene Djevice Marije u Vukovini i povijesne Župe sv. Jurja u Starom Čiču, u: Župa Pohoda Blažene Djevice Marije Vukovina. Povijest baštine i pastoralni rad, (ur.) Ljubica Pernar-Robić - Sanja Cvetnić, Vukovina, 2005., 119-120.

4

»Kapela SS. Fabijana i Sebastijana iz Kuča drvena i stara postala je ruševna, stog sam dao po arhitektu $\mathrm{H}$ pl. Ecklu iz Zagreba načiniti nacrt za novu zidanu pravocrtnu kapelu, koju gradnju je izveo vriedni graditelj Nikola Hribar iz Velike Gorice. Godine 1909., 8. kolovoza porušena je stara kapela i odmah kopani su temelji za novu, koja je došla jeseni iste godine pod krov." Nova zidana kapela blagoslovljena je 3. rujna 1911. godine. - Župna spomenica Liber Rerum Memorabilium pro Parochia Vetero $=$ Chichensi Inceptus Anno 1830 Sub me Parocho Georgio Ruszan. Loci Profati. Tjomulus primus (1830.-1945.), 88-91.

\section{5}

Gradski muzej bio je pod upravom Družbe Braće Hrvatskoga Zmaja, a sve do 1925. godine Laszowski je njime upravljao kao jedini zaposlenik, kada je Gradsko poglavarstvo preuzelo Muzej kao novi vlasnik. Od 1928. godine Gradski muzej preimenovan je u Muzej grada Zagreba. Vidi: FRANJO BUNTAK, Pedeset godina Muzeja grada Zagreba, u: Iz starog $i$ novog Zagreba, I (1957.), 9-35; FRANJO BUNTAK, Muzej grada Zagreba, Zagreb, 1979., 6-9; NADA PREMERL, Povijest Muzeja grada Zagreba u zrcalu stalnih postava, u: Stoljeće Muzeja grada Zagreba 1907.-2007. (ur.) Goran Arčabić, Zagreb, 2007., 30-43; ŽELJKA KOLVESHI, Emilij Laszowski i Gradski muzej u Zagrebu iz perspektive suvremene muzeologije, u: Stoljeće nakon Laszowskog: zbornik radova sa znanstveno-stručnog skupa, Zagreb, 2016., 55-75.

6

Prosvjeta: list za zabavu, znanost i umjetnost, 20 (Zagreb, 15. 10. 1909.), 641.

7

EMILIJ LASZOWSKI - JANKO BARLÈ, Povijest plem. općine Turopolja nekoč Zagrebačko polje zvane. II. Općinske uredbe, povijest crkvi i odnosi nekih crkvenih redova prema općini turopoljskoj, Zagreb, 1911., 274.

8

Glavni oltar tom je prigodom znatno restauriran, o čemu svjedoči visok iznos troška njegove obnove od 350 forinti (usporedbe radi, arhitektu je isplaćeno 400 for.). - SANJA CVETNIĆ (bilj. 3), 22. Usporedbom s fotografijom oltara iz 1909. godine može se zapaziti da su izvršene višestruke preinake, poput uklanjanja bočnih ornamentalnih rezbarenih krila s motivima rešetke, volutnih vitica i listolikih elemenata, uklanjanja skulptura dviju svetica, neznanoga sveca i sv. Ivana Krstitelja na atici, te restauratorski radovi na oltarnim palama. Konzervatorsko-restauratorska istraživanja na oltarnim slikama proveo je Denis Vokić 2006./2007. godine, kada je potvrđeno da je 1911. na oltarnoj pali s prikazom sv. Fabijana i sv. Sebastijana (1648.) izvršen "restauratorski zahvat transferiranja slike sa starog (najvjerojatnije drvenog) nosioca na platno« te da je stavljena "vrlo debela kreda svuda oko svetaca i ornamentirana tako da nalikuje punciranoj koži. Sasvim je izgledno da je slika ranije bila samo prikaz likova bez debele zlatne ornamentacije koja je definitivno nova (tj. 1911.).« - DENIS VOKIĆ, Izvješće o obavljenim konzervatorsko-restauratorskim radovima na slikama Krunjenje Bogorodice i Sv. Fabijan i Sebastijana. Kuče, Župa Vukovina, kapela sv. Fabijana i Sebastijana. Zagreb, 2008. (Dokumentacija Konzervatorskog odjela u Zagrebu.) Taj je restauratorski nalaz tim važniji što se slika spominje kao slikana na koži još prilikom kanonske vizitacije 1695. g., pa se taj podatak prenosi i u kasnijoj literaturi, a spomenuta restauratorska istraživanja ga demantiraju. Zapis kanonskoga pohoda iz 1695. godine glasi: "Ima jedan sitni izrezbareni i malo oslikani retabl, ili bolje rečeno, okvir, na čijoj je sredini slika sv. Fabijana i Sebastijana utisnuta u kožu (preveo Šime Demo). - Nadbiskupski arhiv Zagreb (NAZ), Kanonske vizitacije (KV), Arhiđakonat Katedrala, Protokol 51/VIII, 1695., 63. Zahvaljujemo kolegi dr. sc. Denisu Vokiću na dodatnoj dokumentaciji koju nam je ljubazno ustupio. Konzervatorsko-restauratorska istraživanja i zahvate na arhitekturi i skulpturama glavnoga oltara proveo je Miroslav Pavličić do 2011. godine.

\section{9}

Popis inventara koji je zatekao Janko Barlè 1909. poklapa se sa zajedničkim opisom Laszowskog i Barlèa iz 1911. godine. Zabilježeni su "na strani epistole stari žrtvenik sv. Antuna Pad., a na strani evangjelja žrtvenik sv. Andrije." Osim propovjedaonice, tu su bile i oltarne slike: »U kapeli visjele su i druge stare slike, slikane na platnu. Tako je bila na stijeni kod propovjedaonice stara neukusna slika s natpisom: S. ROSALIA ET SS. FABIANE SEBASTIANE O. P. (...) Tu je bila stara slika sv. Nikole, sv. Ane u okviru s angjeoskim glavicama i napomenute već oltarne slike Preobraženja Gospodinova i sv. Antuna. «Za potonju piše da »ta slika još i danas visi na stijeni u ladji.« - EMILIJ LASZOWSKI JANKO BARLÈ (bilj. 7), 271-274.

10

Pozivi kao i darovani predmeti objavljivani su redovito u dnevnom tisku i časopisima poput Prosvjete, Narodnih novina, Obzora itd. Tako npr. 1907. u časopisu Prosvjeta: list za zabavu, znanost $i$ umjetnost objavljen je poziv i molba u kojima se ocrtava plan uređenja fundusa: »U grad. Muzej (Kamenita vrata I. kat) sabrat će se svekoliki predmeti, važni po kulturu i historiju grada Zagreba i neposredne okoline."Vidi: Prosvjeta: list za zabavu, znanost $i$ umjetnost, 18 (1907.), 583.

11

Riječ je o slikama Sveti Antun Padovanski (MGZ359, stari Inv. br. BHZ 669; ulje na pl., pozl. rezbareni okvir, $80 \times 50 \mathrm{~cm}$ ), Sveti Nikola biskup (MGZ-358, stari Inv. br. BHZ 668; ulje na pl., pozl. rezbareni okvir bez donjeg dijela, $82 \times 50 \mathrm{~cm})$, Majka Božja (MGZ-364, stari Inv. br. BHZ 667; ulje na pl., $39 \times 35$ $\mathrm{cm}$ ), Sveta Ana (stari Inv. br. BHZ 672) te pozlaćenom okviru s anđeoskim glavicama u koji je bila pribijena slika $S v$. Ane (stari Inv. br. BHZ 673). Zahvaljujemo Željki Kolveshi što nam je omogućila pregled građe u Muzeju i uvid u dokumentaciju, kao 
i kolegici Dajani Batinić za fotografije. Nada Premerl donosi da je Laszowski vodio knjigu inventara do 1908. godine s posljednjim rednim inventarnim brojem 252 , da bi potom nastavio $\mathrm{u}$ »ceduljnom katalogu - kartoteci predmeta, koju je vodio do 1926. godine.« - NADA PREMERL (bilj. 5), 36. Vidi također: ŽELJKA KOLVESHI (bilj. 5), 63-65.

12

Bilješka na predmetnoj kartici pod Inv. br. BHZ 670 Kataloga Muzeja Slobodnog i kraljevskog glavnog grada Zagreba.

\section{3}

NELA TARBUK, Kipar Johannes Komersteiner i njegov krug, Zagreb, 2016., 133-137. Više o oltarima kapele u Lazu i župi Marija Bistrica vidi: DORIS BARIČEVIĆ, Kiparstvo baroka u Mariji Bistrici, u: Iz riznice Marije Bistrice, katalog izložbe, Muzeji Hrvatskog zagorja, Muzej seljačkih buna, Gornja Stubica, 1998., 29-30; DORIS BARIČEVIĆ, Kapela sv. Andrije, Laz Bistrički: Oprema kapele, u: Umjetnička topografija Hrvatske: Krapinsko-zagorska županija, (ur.) Ivanka Reberski, Zagreb, 2008., 461.

\section{4}

NELA TARBUK (bilj. 13), 134.

\section{5}

»Retabli građeni ornamentom akantovog lista pripadaju velikoj podskupini oltara koja se proširila na potezu od Češke, Gornje Falačke, Bavarske, Austrije, Slovenije i Mađarske, proživjevši svoje 'zlatno doba' od 1680-ih do 1720-ih godina. Na području sjeverozapadne Hrvatske pojavljuju se na zalasku svoje ere, odnosno, 1719. godine kada je datiran bočni oltar Majke Božje u kapeli sv. Jurja u Jezeru Klanječkome.« - MARTINA OŽANIĆ, Atektonsko građeni oltari XVIII. stoljeća na području sjeverozapadne Hrvatske, doktorska disertacija, Zagreb, Filozofski fakultet, 2017., 154-170. Vidi također: WOLF-DIETER HAMPERL - P. AQUILAS ROHNER, Böhmisch-oberpfälzische Akanthusaltäre, Regensburg, 1984.

16

Znakovit je nedvosmislen Barlèov opis inventara iz 1909. godine: »Na strani epistole je žrtvenik sv. Antuna Pad., a na strani evangjelja žrtvenik sv. Andrije, dok je prije na njem slika Preobraženja Gospodinova, koja i danas visi na stijeni." - Prosvjeta: list za zabavu, znanost i umjetnost, 20 (Zagreb, 15. 10. 1909.), 641.

17

U muzejskoj dokumentaciji samo je jedna slika tog titulara evidentirana (MGZ-359, stari Inv. br. BHZ 669; ulje na pl., pozl. rezbareni okvir, $80 \times 50 \mathrm{~cm}$ ). Razlozi zbog kojih zatečena oltarna pala Svetog Antuna Padovanskog nije sačuvana nisu zapisani, možda zato jer je bila oštećena.

\section{8}

Nije poznato gdje je i je li oltar bio izložen u prijašnjim postavima, osobito u onom prvom u kuli Kamenitih vrata od 1907. do 1925. godine, o čemu Franjo Buntak pojašnjava: »Reporterski prikazi u onovremenskim novinama (1910. i 1917.) davno su već zaboravljeni i danas, osim možda manjeg broja starijih ljudi, nitko više nema jasnije predodžbe o tome, kako je on izgledao: ni o njegovom sadržaju, ni o postavu ni o rasporedu prostorija." - FRANJO BUNTAK (bilj. 5), 12. U novinskom članku o desetogodišnjici Muzeja nepotpisani autor nije pobliže identificirao titular izloženog oltara, nego tek usputno nabraja: »Čim stupimo u prostorije muzeja vidimo izložen jedan drveni oltar i nekoliko crkvenih slika, koje su izradjene u 17 . vijeku kod zagrebačkih Isusovaca." - Deseta obljetnica gradskoga muzeja, u: Narodne novine, 194 (Zagreb, 25. 8. 1917.), 4.
19

Fotografija: Inv. br. MGZ F-73, Muzej grada Zagreba u Opatičkoj 8, detalj crkvene zbirke, stalni smještaj, 1945. godina, Dokumentacija Muzeja grada Zagreba, Stalni postav.

20 Takva je situacija vidljiva na snimkama stalnog postava od 1949. do 1972. godine: MGZ F-91 (Opatička 20, dvorana VII, 1949.), MGZ F-140 (Opatička 20, barokna plastika: drveni oltar i kipovi iz crkve sv. Marka MGZ 375, MGZ 376, MGZ 362.), MGZ F-158 (Opatička 20, detalj dvorane VII prije demontiranja 1959., foto: Nino Vranić lipanj1959.), MGZ F-213 (Opatička 20, barokna plastika iz crkve sv. Marka (prorok Zaharija i kralj David), u sredini oltar iz okolice Zagreba, 18. stoljeće, (foto: Josip Vranić, 1972.) i MGZ F-4344 (Fotografija stalnog postava iz 1965. godine, dvorana VIII. Opatička 20.).

21

Franjo Buntak pojašnjava da su izloženi predmeti bili »u međusobnoj nepovezanosti i bez uspostavljenog dodira s onim bitnim momentima i bez potrebne obrade predstavljali nesistematsku, neizjednačenu, nehomogenu zbirku heterogenih, često puta nebitnih i nevažnih uspomena iz starije i novije prošlosti Zagreba.« Dodaje također da se »u pogledu postava muzeja nije išlo za tim, da se njime dadu određeni sadržaji, da se u njemu dade slika historijskog razvitka grada, već se, kako je to bio običaj, zadovoljavalo time, da muzejski predmeti budu što pravilnije, što estetskije, što ukusnije i ljepše smješteni u izložbenom prostoru.« - FRANJO BUNTAK, Muzej grada Zagreba nekad i danas, u: Muzeji: $m u$ zeološko-konzervatorski časopis, 8 (1953.), 17, 19. Vidi također: NADA PREMERL (bilj. 5), 54. Ovim putem naročito zahvaljujemo Nadi Premerl i Slavku Šterku, dugogodišnjim muzejskim savjetnicima, na tumačenju muzeološke prakse i oživljavanju povijesnih okolnosti u Muzeju.

22

Griesbach je te godine snimao odabrana djela u Strossmayerovoj galeriji za potrebe opremanja nadolazećeg kataloga Galerije iz 1939. godine. U Schneiderovu fotografijskom arhivu je fotografija zavedena pod brojem SFA-1084, Zagreb, Muzej grada Zagreba, Oltar iz kapele Svetoga Antuna u Kučama, XVII. st. Vidi: ĐURO VANĐURA - BORIVOJ POPOVČAK - SANJA CVETNIĆ, Schneiderov fotografijski arhiv: hrvatski spomenici kulture i umjetnosti, (ur.) Andre Mohorovičić, Zagreb, 1999., 324. Zahvaljujemo kolegici Indiri Šamec-Flaschar iz Strossmayerove galerije starih majstora u Zagrebu na pomoći oko utvrđivanja okolnosti nastanka ove fotografije.

\section{3}

Izgledno je da je upravo ta skulptura Boga Oca dio grupe Krunidbe Bogorodice zajedno sa skulpturom Bogorodice (MGZ-2616, v. 65 $\mathrm{cm})$ i Krista (MGZ-1286, v. $68 \mathrm{~cm}$ ), koje su krasile atiku bočnoga oltara Obraćenja svetoga Pavla, a koji je ceh čizmara podigao 1760. godine u župnoj crkvi sv. Marka u Zagrebu. Oltar je zajedno s ostalim inventarom uklonjen prilikom Schmidt-Bolléova uređenja crkve od 1876. do 1882. godine, a danas se nalazi u fundusu Povijesnog muzeja u Zagrebu. U iznimnoj kvaliteti kiparskog oblikovanja zrcali se znalačka ruka majstora koja bi mogla pripadati, a što dosad u literaturi nije bilo prepoznato, najmlađem potomku glasovite bavarske obitelji Franzu Antonu Straubu (1726.-1774/6.), koji se 1760-ih godina iz Graza doselio u Zagreb, gdje je njegova radionica na Opatovini djelovala desetak godina. Usp. VANDA LADOVIĆ, O baroknoj plastici iz crkve sv. Marka, u: Iz starog i novog Zagreba, IV (Zagreb, 1968.), 140.; DORIS BARIČEVIĆ, Barokna skulptura na Gradecu, u: Zagrebački Gradec 1242.-1850, (ur.) Ivan Kampuš - Lujo Margetić - Franjo Šanjek, Zagreb, 1994., 367; SNJEŽANA PAVIČIĆ, Sakralno kiparstvo u Hrvatskom povijesnom muzeju u Zagrebu, Zagreb, 2003. 
36, 38, 92-93; DORIS BARIČEVIĆ, Barokno kiparstvo sjeverne Hrvatske, Zagreb, 2008., 371, 429.

\section{4}

Očito je da takva muzeološka praksa nije bila neuobičajena, za što potvrdu nalazimo primjerice na drugoj fotografiji iz Schneiderova arhiva (SFA-1086) snimljenu također tom prigodom. Na njoj je prikazana slika Bičevanja Krista koja, međutim, potječe iz kapele Ranjenoga Isusa u Zagrebu. Drvorezbareni okvir od rokajnog ornamenta u koji je slika ubačena vrlo je srodan okviru na oltaru sv. Roka, odnosno Presvetog Trojstva, sv. Ivana Krstitelja i sv. Ivana Evanđelista, koji se danas nalazi u kapeli sv. Roka na Rokovu perivoju, a koji je izvorno bio u župnoj crkvi sv. Marka u Zagrebu. Više o oltaru i konzervatorsko-restauratorskim istraživanjima vidi: IVA KOCI - SENA KULENOVIĆ, Skriveno u vidljivom istraživanja oltara sv. Roka iz kapele na Rokovu perivoju, u: Portal. Godišnjak Hrvatskog restauratorskog zavoda, 4 (2013.), 139-151.

\section{5}

Nada Premerl donosi podatak da se krajem 1960-ih godina "pristupilo sukcesivnoj obnovi« stalnog postava koji je »obnavljan s entuzijazmom i velikim osobnim zalaganjem postavljača etapno desetak godina.« Tako je 1968. godine otvorena prva dvorana s novim postavom, a cjelokupna obnova postava dovršena je 1978. godine. Postav koji je pokrivao razdoblje od 15. do 18. stoljeća otvoren je 3. srpnja 1975. godine, no tada oltar Preobraženja Gospodinova više nije bio uvršten. - NADA PREMERL (bilj. 5), 60-61. Postoje naznake da su vjerojatno dva velika reljefa $s$ anđelima u akantovu lišću bila izložena i u sklopu novoga postava 1977. godine, što se nazire u obrisu na snimci obnovljenog stalnog postava. Usp. NADA PREMERL (bilj. 5), 61.

\section{6}

HELA VUKADIN-DORONJGA, Stručno mišljenje o povratu (desnog) bočnog oltara Preobraženja Gospodinova (Kuče, Kapela Sv. Fabijana i Sebastijana / Župa Pohoda Blažene Djevice Marije, Vukovina) iz fundusa Muzeja grada Zagreba (oltar darovan MGZu 1911. godine, Adam Podolšak, župnik, Staro Čiče; MGZ 362). Muzej grada Zagreba: arhivska dokumentacija, 2014.

27

Ministarstvo kulture, Klasa: 612-05/14-01/0105, Ur. broj: 53205-01-03/4-14-03, 17. 4. 2014. Osobito zahvaljujemo dr. sc. Heli Vukadin-Doronjga, višoj kustosici Muzeja, koja se spremno založila za povrat oltara na njegovu izvornu lokaciju.

28

Posljednjih godina često se povezuje i s temom repatrijacije umjetnina otuđenih i muzealiziranih tijekom okupacije.

29

Od 1972. godine raspelo je bilo izloženo u Pinakoteci u Trogiru, a inicijativom dr. sc. Joška Belamarića i Radoslava Bužančića vraćeno je na izvorno mjesto 2000. godine. Ekskluzivnost tom podvigu daje i činjenica da je to jedna od prvih demuzealizacija u Europi, s obzirom na to da je Giottovo raspelo vraćeno u crkvu Santa Maria Novella u Firenzi mjesec dana poslije. - ŽANA MATULIĆ-BILAČ, Christus triumphans - Slikano raspelo iz crkve Sv. Andrije na Čiovu, u: Portal: godišnjak Hrvatskog restauratorskog zavoda, 4 (2013.), 73-103, 95, zajedno s literaturom koju navodi.

30

Vidi: MARIN IVANOVIĆ, Nove smjernice za uređenje svetišta, u: Katedrala Gospe Velike u Dubrovniku, (ur.) Katarina HorvatLevaj, Dubrovnik - Zagreb, 2014., 489-492.

31

Istražna sondiranja, zbog destruktivnosti metode, nisu provedena, ali je provedeno nedestruktivno analiziranje materijala rendgen- skom fluorescentnom spektroskopijom kojom je ustanovljena prisutnost smalta, pigmenta koji se osobito često u 17. stoljeću koristio za svjetloplave plohe. Hrvatski restauratorski zavod (dalje HRZ), Prirodoslovni laboratorij, Domagoj Mudronja, Laboratorijsko izvješće br. 316/2016.

32 Zahvaljujemo Mariju Braunu koji je izradio RTG, IC i UV snimak te dr. sc. Ireni Bratičević koja je pomogla dešifrirati natpis.

33

Laszowski i Barlè (1911.) prenose da je arhiđakon Josip Mikinović 1768. godine zatekao župnu crkvu zapuštenu i u jako lošem stanju. Napori da se spasi crkva zabilježeni su 1777 . godine kada je Plemenita općina Turopoljska dostavila hrastova stabla za popravak krova. Pokušaji nisu urodili uspjehom jer je već 1799. godine postala područna crkva, a crkva u Vukovini dobila status župne crkve. Vidi: EMILIJ LASZOWSKI - JANKO BARLÈ (bilj. 7), 309; ANĐELA HORVAT, Prilog poznavanju spomenika NO općine Velika Gorica (Turopolje), u: Spomenici kulture Turopolja. Vijesti muzealaca i konzervatora Hrvatske, 5, godina X., (1961.), 145.

34

Indikativno je da se prilikom kanonskih pohoda u bilješkama o računima ne spominje ime kanonika Škrleca, što bi upućivalo da je o svojem trošku namirio cjelokupnu izradu oltara te ga gotovoga darovao župnoj crkvi.

35

LJUDEVIT IVANČAN, Podaci o zagrebačkim kanonicima od 1193. do 1924. Zagreb: Nadbiskupski arhiv Zagreb, 1924., 569. Laszowski (1908.) spominje kanonika Ivana Škrleca 1632., 1635. i 1650. godine. Vidi: EMILIJ LASZOWSKI, Povijesni spomenici plem. općine Turopolja, svezak IV. god. 1560.-1895., (sabrao i troškom iste općine izdao Emilij Laszowski) Zagreb: tiskom Antuna Scholza, 1908., 141; 533; 543. Laszowski (1911.) također piše da su »godine 1668. u Vukovini postojale dvije kurije: vukovinska i kurija pok. Ivana Škrlca, koju su onda posjedovali zagrebački isusovci.« Vidi: EMILIJ LASZOWSKI - JANKO BARLE (bilj. 7), 309.

36

EMILIJ LASZOWSKI (bilj. 35), 533. Također: Državni arhiv u Zagrebu, signatura fonda: HR-DAZG-827 (dokumenti obitelji Pogledić iz 1560.-1892.).

\section{7}

Zapisi iz 1642. godine u župnoj crkvi u Starom Čiču navode da je od tri oltara samo glavni posvećen, što sugerira da su nabavljeni novi u razdoblju od prethodne kanonske vizitacije iz 1630. godine, kada je arhiđakon zabilježio da su sva tri oltara posvećena. Zapisi iz 1649. godine pak izrijekom navode da su sva tri oltara (glavni oltar, bočni oltar sv. Marije Magdalene i bočni oltar Navještenja Marijina) posvećena što je terminus ante quem njegovog nastanka. Vidi: Nadbiskupski arhiv Zagreb (NAZ), Kanonske vizitacije (KV), Arhiđakonat Katedrala, Protokol 3/III, 1630., 17; 1642., 149.; 2/II, 1649., 21v.

38

Ljudevit Ivančan bilježi da je Škrlec "prisegao za zagreb. sjemenište 12. II. 1640., a za bečki kolegij 12. X. 1642. Postavši Petretić god. 1648. zagreb. biskupom podijelio mu je svoj kanonikat. God. 1651. bio je vrbovački, 1653. bekšinski arhidjakon, a iza smrti Ambrozija Jaškaja postao je g. 1655. kantor. «- LJUDEVIT IVANČAN (bilj. 35), 569.

39

"Ad cornu epistolae est tertium altare, muratum, non consecratum, quod ornatur altari ligneo, arculario et sculptorio opere facto et picto, modice inaurato, in cuius medio est imago Beatae 
Magdalenae. [Na strani poslanice nalazi se treći oltar, zidan i neposvećen, sa stolarskim i izrezbarenim, oslikanim i malo pozlaćenim oltarom, na čijoj se sredini nalazi prikaz svete Marije Magdalene (preveo ŠIME DEMO).] « - NAZ, KV, Arhiđakonat Katedrala, Protokol 46/II, 1678., 236.

\section{0}

"...altare unum antiquum, emptum ab ecclesia parochiali fl. Rh. 3 xr. 40. [Nabavljen je jedan stari oltar, kupljen od župne crkve za 3 rajnske forinte i 40 krajcara. - "Nabavljen je « preneseno je iz prethodnog dijela rečenice: aucta'. (preveo i protumačio ŠIME DEMO)]. - NAZ, KV, Arhiđakonat Katedrala, Protokol 48/IV, 1685., 72.

41

Florijan Pavlinić je bio župnik u Starom Čiču od 1682. do 1698. godine. EMILIJ LASZOWSKI - JANKO BARLÈ (bilj. 7), 291-292.

\section{2}

„Oltari u župnoj crkvi podignuti iz zadužbine pokojnoga Stjepana Katulića, rodom iz Starog Čiča, župnika u župi sv. Martina biskupa i ispovjedaoca u Martijancu. [Isplata na temelju oporuke, u iznosu od 200 forinti, izvršena je 3. studenoga 1689. (preveo i protumačio ŠIME DEMO).] « - NAZ, KV, Arhiđakonat Katedrala, Protokol 49/V, 1689., 178.

43

Zapis kanonskoga pohoda iz 1692. godine: "Na strani evanđelja nalazi se drugi oltar, zidan i neposvećen, nad kojim stoji drugi, drveni oltar, stolarski i kiparski rad, obojan i pozlaćen, koji na sredini ima sliku sv. Marije Magdalene pokajnice, između kipova sv. Florijana i sv. Nikole biskupa i ispovjedaoca. Na gornjoj razini oltara nalazi se slika sv. Katarine, a sa strana su joj pozlaćeni kipovi sv. Jeronima i Ambrozija. Na samom se vrhu oltara nalazi maleni kip sv. Mihaela arkanđela (preveo ŠIME DEMO). « - NAZ, KV, Arhiđakonat Katedrala, Protokol 50/VI, 1692., 121; Zapis iz 1695. godine: »Nadalje, u ovoj crkvi nalazi se i sporedni oltar, zidan i neposvećen, i to smješten u lađi crkve na strani evanđelja, pod imenom sv. Marije Magdalene. Urešen je drvenim pločama i stupovima, koji su stolarski, kiparski i slikarski rad. Na sredini donje razine postavljena je slika sv. Marije Magdalene naslikana na platnu, a sa strana se između stupova nalaze rezbareni i pozlaćeni kipovi sv. Florijana i Nikole biskupa. Na gornjoj se pak razini na sredini nalazi slika sv. Katarine djevice i mučenice na platnu. Sa strana se između stupova nalaze izrezbareni i pozlaćeni kipovi sv. Augustina i Ambrozija. A na samome je vrhu klesani i pozlaćeni kip sv. Mihaela arkanđela (preveo ŠIME DEMO).« - NAZ, KV, Arhiđakonat Katedrala, Protokol 51/VIII, 1695., 49.

\section{4}

»Kapela je drvena i blagoslovljena. U njoj se nalazi drveni oltar, na kojemu su slike sv. Fabijana i Sebastijana. Sa strane je izrezbareni oltar sv. Antuna Padovanskog, na kojemu se nalazi slika istoga sv. Antuna." - NAZ, KV, Arhiđakonat Katedrala, Protokol 50/VI, 1692., 126; Opis iz 1695. neznatno je detaljniji: »U ovoj se kapeli nalazi jedan oltar postavljen u njezino svetište, drven, pod imenom sv. Fabijana i Sebastijana. Ima jedan sitni izrezbareni i malo oslikani retabl, ili bolje rečeno, okvir, na čijoj je sredini slika sv. Fabijana i Sebastijana utisnuta u kožu. (...) Nadalje, u ovoj kapeli nalazi se i drugi oltar, i to smješten u njezinu lađu, pod imenom sv. Antuna Padovanskog; drven je i ima stare izrezbarene, oslikane i malo pozlaćene ploče i stupove. Na sredini se nalazi slika sv. Antuna Padovanskoga na platnu (preveo ŠIME DEMO).« - NAZ, KV, Arhiđakonat Katedrala, Protokol 51/VIII, 1695., 63.

45

Dimenzije slike Sveti Antun Padovanski (MGZ-359) su $80 \times 50$ $\mathrm{cm}$, dok su dimenzije slike Preobraženje Gospodinovo (MGZ-361) $105 \times 84 \mathrm{~cm}$.
46

Vidi: ANĐELA HORVAT (bilj. 1), 388-390; DORIS BARIČEVIĆ (bilj. 23, 2008.), 16-26.

47

Vidi: MARTINA OŽANIĆ (bilj. 15), 32-41.

48

Prirodoslovni laboratorij Hrvatskoga restauratorskog zavoda, Margareta Klofutar, Laboratorijsko izvješće br. 314/2016.

49

FRITZ BUCHENRIEDER, Gefasste Bildwerke, München: Bayerisches Landesamt für Denkmalpflege, 1990., 76.

50 NAZ, KV, Arhiđakonat Zagorje, protokol 22/IV, 1729.: »Columnullas habet 2 . Ceruleo colore tinctas et sparsim inauratas."

51 NAZ, KV, Arhiđakonat Gora, protokol 11/II, 1696.; 12/III, 1729.: "... inter 2. columnas ad formam lapideam factas... "Više o istome u: KSENIJA ŠKARIĆ, Disliked - improved - surviving. Seventeenth-century altars in Inland Croatia, their polychromy and its role in their reception, u: Restauratorenblätter (Reflexionen für Manfred Koller/ Reflections to Manfred Koller), 31 (2012.), 103-108, 107; ISTA, Polikromija i polikromatori oltara 17. i 18. stoljeća u sjeverozapadnoj Hrvatskoj, doktorska disertacija, Zagreb: Filozofski fakultet Sveučilišta u Zagrebu, 2014.

52 S obzirom na to da su krila izgubljena, u grafičkoj simulaciji pribjeglo se jednostavnom obliku i nenapadnom koloritu.

53

Manje je vjerojatno da se na postamentu nalazila skulptura, kao što je to, primjerice, na pobočnom oltaru sv. Blaža iz 1663. godine u crkvi Uznesenja Marijina u Glogovnici. Oltar se, doduše, u zapisima kanonskih vizitacija naziva stolarskim i kiparskim radom (»arculario et sculptorio opere facto«), ali se skulptura na vrhu nigdje poimence ne spominje.

54

Osim navedenih oltarnih primjera, prizmatične profilacije nalaze se i na bočnom oltaru sv. Roka u kapeli sv. Ivana Krstitelja/Rastanka Apostola u Buševcu, također filijalnoj kapeli Župe Staro Čiče, odnosno danas Župe Vukovina. Oltar je vidljivo preinačen tijekom vremena, no osnovna arhitektonska konstrukcija te sačuvan ornamentalni motiv dijamanta na trabeaciji jasan je putokaz za dataciju oltara u prvu polovinu 17. stoljeća. Vidi: MARTINA OŽANIĆ (bilj. 15), 32.

55

MILAN ŽELEZNIK, Osnovni vidiki za študij »zlatih oltarjev« v Sloveniji, u: Zbornik za umetnostno zgodovino IV, (1957.), 164-165; U novije vrijeme ovu je temu detaljnije istražila: MARTINA WOLFF ZUBOVIĆ, Tipologija i podrijetlo ornamentike na drvenim oltarima XVII. i XVIII. stoljeća na području sjeverozapadne Hrvatske - recepcija, primjena i razvoj motiva, doktorska disertacija, Zagreb: Filozofski fakultet Sveučilišta u Zagrebu, 2017. Vidi također odjeljak o rezbarenom ukrasu u MIRJANA REPANIĆ-BRAUN - KSENIJA ŠKARIĆ - MARTINA WOLFF ZUBOVIĆ - HELENA CAVALLI LADAŠIĆ, Oltar sv. Wolfganga u Vukovoju, u: Portal: Godišnjak Hrvatskog restauratorskog zavoda, 4, (2013.), 117-138.

56

Njegov traktat Architectura o redovima i "arhitektonskim fantazijama« iz 1577. godine ostavio je zamjetan trag na djelima sljedećih generacija. PETRA SOPHIA ZIMMERMANN, Die "Architectura« von Hans Vredeman de Vries. Entwicklung der 
Renaissance Architektur in Mitteleuropa, München, Berlin: Deutscher Kunstverlag, 2002.

57

Vrlo je utjecajna bila njegova knjiga o arhitektonskom ornamentu i redovima "Architectvra: Von Außtheilung, Symmetria vnd Proportion der Fünff Seulen« (1593., 1594., 1598.). Vidi: ERIK FORSSMAN, Säule und Ornament - Studien zum Problem des Manierismus in den nordischen Säulenbüchern und Vorlageblättern des 16. und 17. Jahrhunderts, Stockholm, 1956.

\section{8}

Među istaknutim njegovim djelima je "Architectura Oder Verzeichnuß allerhand Einfassungen an Thüren, Fenstern und Decken«, izdana 1609. u Frankfurtu na Majni. HANNO-WALTER KRUFT, History of Architectural Theory, From Vitruvius to the present, New York, 1994. (München, 1985.), 168-171.

\section{9}

Krammerova knjiga Architectura »Von Den Funf Seulen Sambt Iren Ornamenten Und Zierden«, objavljena 1600. u Kölnu, odnosno 1606. godine u Pragu bila je naročito uspješna. FELICITAS ROTHE, Das deutsche Akanthusornament des 17. Jahrhunderts, zur Frage seiner Selbständigkeit. Berlin, 1938.
60

Vinjete su najčešće bile slikane bijelom, žutom ili zlatnom bojom na crnoj ili modroj podlozi. Bijele nalazimo na oltaru iz Muzeja grada Zagreba i na spomenutom oltaru u kapeli sv. Martina u Martinščini, a žute odnosno zlatne na oltaru sv. Lovre u Starom gradu Varaždinu iz 1617. i na okviru slike Raspeće u Gornjem Tkalcu iz 1674. godine.

61

Iluziju rezbarenog ukrasa na plošnim oltarnim krilima možemo vidjeti na oltaru sv. Lovre u Starom gradu Varaždinu iz 1617. godine i na bočnom oltaru Svete Obitelji u kapeli Uznesenja Blažene Djevice Marije u Gornjem Tkalcu iz 1628. godine (na restauratorskoj sondi).

62

O ornamentu okovlja na oltarima sjeverozapadne Hrvatske vidi: MARTINA WOLFF ZUBOVIĆ (bilj. 55)

63

Često se dešavalo i to da su strani majstori pozivani da narudžbu izvedu ovdje. S obzirom na jednostavnu konstrukciju, a ambiciozan oslik izražene kvalitete, sasvim je moguće da je stolar bio domaći, a slikar gostujući.
Concerning the fact that only a few altars from the first half of the $17^{\text {th }}$ century have remained preserved in continental Croatia, new insights about them are always noteworthy, especially when they concern artefacts of considerable artistic value, such as the altar presently dedicated to the Transfiguration and originally from the chapel of St Fabian and St Sebastian in the village of Kuče in the parish of (formerly Staro Čiče). Comparative material and archival research has revealed a series of hitherto unknown facts, including its date, the previous titular saint, the commissioner/donor, and the sequence of its transfers. Along with several other artworks from the Kuče chapel, the altar was donated to the Museum of the Free Royal City of Zagreb (today's Municipal Museum) in 1911 by parish priest Adam Podolšak, when the derelict wooden chapel from the $17^{\text {th }}$ century was torn down and a new one built according to the design of architect Hector Friedrich Wilhelm Maria von Eckhel (Trieste, 1855 - Zagreb, 1934). The Museum had been founded shortly before, in 1907, sponsored by the Society of the Brethren of the Croatian Dragon and largely owing to the initiative of Emilij Laszowski (Brlog kraj Ozlja, 1868 - Zagreb, 1949), historian, archivist, and its first director and curator. Together with historian Jankom Barlèo (Budanje kod Vipave, 1869 Zagreb, 1941), Laszowski visited numerous monuments in the Turopolje region and was the last to describe the interior of the old wooden church.

The retable was displayed at the Museum combined with two larger reliefs with the figures of torch-bearing angels among acanthus ornaments, from the workshop of sculptor Johannes Komersteiner, which were added instead of the missing pillars, and another, smaller relief of unknown provenance added to the predella. In this form, the altar was part of the permanent exhibition from 1945 at Opatička No. 8, as well as the one at Opatička No. 20 from 1946 until the 1970s, when it was moved to the museum depot.

The architecture of the retable displays features typical of the altar programmes from continental Croatia during the first half of the $17^{\text {th }}$ century: a simple, flat construction of the aedicule with an image between the pillars, painted with ornamental and figural motifs, and decorated with silvercoated and lacquered gem motifs. Rests of grains reveal that the pillars had a granulated coating, which is the earliest attested example of this extremely rare design and technique in continental Croatia, the other known examples being those of Martinščina (from the 1660s) and Brest Pokupski (ca. 1696). The predella inscription tells us that the altar was dedicated to St Anthony of Padua, but an X-ray shot of 
the inscription has shown that it hides an older inscription, showing that the altar had formerly been dedicated to St Mary Magdalene. This older inscription also reveals the name of the commissioner and possible donor: Zagreb's canon Ioannes Skerlecz (Ivan Škrlec, d. 1659). The chapel in Kuče never had an altar dedicated to St Mary Magdalene, since the one in question came there from the old parish church of St George in Staro Čiče, which is confirmed by the records of a canonical visitation from 1685, which tells that a sum of 3 Rhine guldens and 40 kreutzer was paid for "an old altar from the parish church." The altar of St Mary Magdalene was first mentioned during the canonical visitation of the parish church in 1649 , which is the terminus ante quem for its production. Its artistic quality and the skilful hand of an anonymous painter indicate the ambitions and knowledge of its commissioner, as well as links with good workshops beyond the local setting.

After more than a hundred years, the altar is about to return from the museum to the chapel of St Fabian and St Sebastian in Kuče, which makes it the first de-musealized and re-sacralized altar in Croatia.

Keywords: Kuče, Staro Čiče, de-musealization, re-sacralization, wooden altar, $17^{\text {th }}$ century, Johannes Komersteiner, Municipal Museum of Zagreb 